\title{
OS VALORES DAS ENFERMEIRAS NA INTENÇÃO DO AGIR ÉTICO
}

Tese apresentada à Escola de Enfermagem da Universidade de São Paulo para a obtenção do título de Doutor em Enfermagem

Orientadora:

Prof $^{\mathrm{a}}$ Dr $^{\mathrm{a}}$ Eliane Corrêa Chaves

\section{SÃO PAULO \\ 2004}




\section{I NTRODUÇÃO}

Em minha vida profissional como enfermeira, depois como docente, de forma direta ou indireta prestava cuidados ao paciente sem uma reflexão sobre o que essa assistência poderia representar para aqueles a quem assistia e nem o que significava para mim.

Acredito que estas reflexões surgiram na época do mestrado, quando me propus a estudar a vivência do paciente cuidado por aluno de enfermagem. Embora não tenha sido o objetivo do trabalho em questão, nos discursos dos pacientes apareceu uma comparação da relação estabelecida entre paciente e aluno e paciente e enfermeiro, na qual eles relataram que se ressentiam da falta de atenção e disponibilidade do enfermeiro e encontravam isso na relação com o aluno. $^{(1)}$

Algum tempo depois, cursando a disciplina "A história dos valores e do pensamento"*, outros questionamentos destacaram-se com relação à prática do enfermeiro, aos valores que permeiam esta prática e à maneira de prestar o cuidado. Em aula, fazíamos exercícios de reflexão sobre nossas atividades, baseados em alguns valores, tais como: verdade, vontade, compaixão, poder e liberdade.

\footnotetext{
* Disciplina oferecida no Programa de Pós-Graduação em Enfermagem na Saúde do Adulto, ano de 2000.
} 
Em uma das aulas, quando discutíamos poder e liberdade, lembrei-me de uma situação vivenciada durante a hospitalização de um paciente que, após alguns dias de internação, referiu que nunca havia prestado atenção no quanto eram fortes as palavras, embora ditas com docilidade: "tem que", "o senhor tem que tomar banho", "tem que tomar este remédio" e ainda o fato de perguntar-me se eu ensinava isso a meus alunos.

Nesse momento, fiquei sem ação e comecei a pensar quantas vezes agi dessa forma, tendendo sempre a prestar os cuidados, segundo critérios que estabeleci como corretos ou mais importantes sustentados pelos preceitos científicos disponíveis, induzindo o paciente a agir como eu acreditava que fosse melhor.

Hoje, com mais clareza, percebo que, durante a assistência prestada ao paciente, sua vontade é cerceada ou desconsiderada e, muitas vezes, não lhe é dada opção de escolha, talvez, porque em nossa estrutura profissional restringir a liberdade de alguém não seja um problema pois, na maioria das vezes, o que se pretende obter por meio do cuidado é a recuperação da saúde e, na concepção de saúde mecanicista, na qual o sistema vigente apóia-se, o desenvolvimento do ser humano ou o resgate de sua condição humana mais ampla não tem necessariamente tangência com a saúde.

A propósito disso ao comentar sobre a prática médica tradicional e o uso da "supertecnologização", Serino(2) afirma que 
a pessoa do doente fez suas queixas, contou sua história e ofereceu seu corpo como palco. Dali por diante, passou a ser platéia, muitas vezes, intensamente ansiosa pelo desenrolar de um enredo do qual ela não mais participa ativamente.

Nesse trabalho, a autora citada dá ênfase à sua percepção com relação à preocupação dos profissionais com a doença, às tecnologias e sua própria prática, aparentemente, sem se importar com o sujeito, aquele que é o objetivo de suas ações.

$\mathrm{Na}$ assistência ao paciente, muitas vezes, este tenta fazer suas escolhas ou tomar suas decisões, mas, por acharmos que podemos fazer melhores escolhas que ele e por "sabermos" o que é melhor para ele, na maioria das vezes, ignoramos suas vontades, decisões, valores, história de vida e cultura.

Dessa forma, desconsiderar mesmo que, temporariamente, a necessidade e o direito de um ser humano de fazer suas escolhas pode ser um descuidado, ou mais do que isso, uma violência ao processo de refinamento de sua condição humana.

É possível que cuidados de enfermagem sejam mais terapêuticos no sentido amplo da palavra, que busquem a conciliação entre as questões sociais, psicológicas, filosóficas e biológicas do ser humano do que ações diretivas e impositivas voltadas apenas a mudanças dos hábitos cotidianos e à obediência rígida de padrões de 
terapêuticas, nos quais os enfermeiros fundamentam seus protocolos de assistência.

De qualquer modo, sejam quais forem os modelos assistenciais escolhidos pelos enfermeiros, individual ou coletivamente, estes em última instância são expressões fenomênicas de um sistema de crenças e valores relativos à saúde, à doença, à vida, à morte e a vários outros temas que Ihes são concernentes.

Embora sejam fundamentos do agir profissional do enfermeiro, esses valores nem sempre são claramente identificados por eles ou eleitos a partir de um processo de escolha refletida e madura. Muitas vezes, pode ocorrer inclusive um distanciamento entre seus atos e os fundamentos éticos desses atos que os enfermeiros podem não identificar o significado de seu cuidar de modo nítido.

Dentre as preocupações que motivaram as reflexões filosóficas, desde os primórdios da cultura ocidental, é possível que a Ética tenha sido uma das primeiras. Assim, a premissa pela qual nosso agir sustenta-se em valores éticos iniciou-se na ética de Aristóteles. Para ele, nossas virtudes e, por conseguinte, nossos valores, não são dons apenas naturais, são predisposições que possuímos e que apenas se constituíram como tal, ou seja, deixaram de ser possibilidade para ser fato na medida que as exercemos em nossos atos.

Expressando suas idéias relativas à ética, mas, voltadas para o agir dos aristocratas, Aristóteles entendia que "a nobreza é, pois, 
menos assunto de natureza ou mesmo de costume, do que uma capacidade de multiplicar os atos de bravura e as proezas". (3)

Esta afirmação resume o conceito aristotélico, pois as aptidões e virtudes inatas dos homens são apenas possibilidades e a transformação destas possibilidades em fatos depende do esforço e da dedicação consciente dos homens, e no processo de refinamento da natureza humana no qual o agir ético ocorre. Conforme Aristóteles, para isto concorrem três elementos que são considerados imprescindíveis: a educação, a transcendência do ato sobre os costumes e a visibilidade da ação moral. Em linguagem contemporânea, na expressão desses três elementos, supõe-se que Aristóteles referia-se ao que agora entendemos por: reflexão discutida de questões sobre ser e agir, a crença na supremacia do agir consciente sobre o agir habitual e, necessariamente, a expressão fenomênica do produto final desse processo em atos.

O primeiro teórico a vincular o pensar ético ao agir ético, foi Aristóteles que deu origem a uma corrente filosófica baseada nessa vinculação, seguida nos séculos XVII e XVIII pelos empiristas e utilitaristas e, contemporaneamente, pelos neopositivistas e pelos componentes da filosofia analítica.

Um exemplo disso é Hare ${ }^{(4)}$, ao afirmar que

a pessoa pode colocar em seu discurso todos os princípios que considera em suas ações, mas, diante das escolhas ou decisões, entre as respostas do que "deve ser feito", ela 
revelaria em quais princípios de conduta realmente acredita.

Observando os pressupostos de Aristóteles e dos demais filósofos que deram seguimento à sua corrente filosófica ética e articulando tais pressupostos com a realidade particular e cotidiana do enfermeiro em seu exercício de cuidar de outro ser humano, parece importante desvendar as perspectivas, nas quais se verifica o processo de apropriação do agir ético do enfermeiro, sobretudo, se considerarmos a complexidade que caracteriza o fenômeno "cuidar de alguém" e os dilemas éticos que dele decorrem.

O modo de vida contemporâneo baseado, especialmente, em valores pragmáticos e mercantilistas, parece nos impor um cotidiano que, na maioria das vezes, se incompatibiliza com reflexões relativas a nosso agir. Raramente pensamos e optamos de modo consciente pela finalidade de nossos atos. Por quê agimos desta ou daquela maneira? 0 que queremos obter com nossas ações? Qual o propósito de nossas escolhas? Nossos atos são, realmente, conscientes, ou melhor, são éticos?

É freqüente, também, nos surpreendermos respondendo a tais perguntas em forma de justificativa, em especial, no que diz respeito às ações profissionais: “agimos assim, porque aqui a rotina é essa, ou o protocolo para este tipo de paciente é este", ou ainda, "ajo assim, porque os resultados das pesquisas mais recentes sobre este assunto afirmam que". 
Parece-nos óbvio e desejável agirmos, de acordo com o que é preconizado na instituição de saúde a que pertencemos, o mesmo se aplica à consonância de nosso agir com as ciências que dão sustentação teórica a nosso exercício profissional. No entanto, não nos parece óbvio nem desejável que estes dois balizadores de nosso exercício profissional substituam nossas opções éticas em relação a nosso agir, profissional ou não.

No auge do Renascimento, do Iluminismo e do Positivismo, o conhecimento científico chegou a ser assimilado como a única possibilidade de desvendar as verdades absolutas. Talvez, nesses momentos históricos, não fizesse muito sentido questionar um agir cientificamente sustentado.

Essas épocas, ao mesmo tempo confortáveis e ingênuas vêm sendo superadas, pelo menos, há cem anos e hoje sabemos que a ciência só é capaz de nos apresentar possibilidades de certezas e, conseqüentemente, verdades não absolutas. O fato já seria suficiente para justificar a imperiosidade de buscarmos respostas às questões apresentadas anteriormente, no entanto, uma outra questão parece ser de modo absoluto relevante para justificar a importância da reflexão ética na tomada de decisão profissional diante de afirmações científicas: o fato do ser humano ser ontologicamente consciente. Em termos genéricos, não há humanidade sem consciência e, consensualmente, ter consciência implica livre arbítrio e, portanto, escolhas. Estas, por sua vez, requerem definições de sentido, direção e finalidade. 
Quando pensamos em relações humanas, particularmente, nas quais existe intimidade, seja por opção ou por necessidade (como é o caso da relação paciente-enfermeiro), a opção ética do agir torna-se muito mais complexa do que na maioria das outras situações. Os conflitos resultantes das incompatibilidades entre as escolhas dos sujeitos tendem a ser mais contundente. Surgem os dilemas éticos tão freqüentes, tão difíceis de serem administrados, mas, cuja superação é necessária para o desenvolvimento psicoafetivo e ético dos envolvidos, assim como para a competência profissional e a possibilidade de felicidade para ambos.

Pensando nas indagações que vêm se desenvolvendo, percebeu-se a necessidade de buscar material que pudesse dar sustentação a esses questionamentos com base nos conceitos sobre valores.

\subsection{O CONHECI MENTO DOS VALORES}

Considerando que "o sentimento da vida de um homem é dado pelos valores e, por meio deles o homem vive plenamente a sua condição humana" ${ }^{(5)}$, é possível observar que o indivíduo exerce uma atitude axiológica diante de tudo que o cerca, sendo com isso capaz de julgar se alguma coisa é boa ou ruim, agradável ou desagradável, justa ou injusta. 
O homem percebe que todas as coisas que o cercam, possuem um determinado valor e, diante disso, sempre assume uma escolha, podendo aceitá-la ou rejeitá-la, mas por um ato de vontade, não é possível passar indiferente frente a esses valores.

Desde a Antigüidade Clássica, os valores são tratados e tiveram como primeiro pensador Sócrates com o combate ao relativismo e subjetivismo dos sofistas e a luta pela objetividade dos valores éticos. Para Platão, o caminho foi por meio da teoria das idéias, precisamente, a idéia do bem, dos valores éticos e estéticos. Com Aristóteles, as idéias passam a ancorar-se nas coisas e na realidade.

Na filosofia moderna, Kant deu a maior contribuição, em posição oposta a Aristóteles, à idéia de valor, que saiu do Cosmos para o domínio da consciência e a "consciência moral torna-se a verdadeira pátria dos valores éticos". (6)

Tal como Aristóteles, Kant coloca sua ética em direção oposta aos hábitos e costumes; no entanto, busca construir uma ética "coletiva", ou seja, procura um princípio universal para as ações humanas. Parte do pressuposto que existem alguns valores (embora não utilize este termo) que não dependem do discernimento particular dos homens, mas estariam presentes nestes de modo inato, e eles poderiam conhecê-los por dedução racional e, a partir disso, decidiriam como agir.

Embora não tenha utilizado o termo "valores", o conceito relativo a ele já estava presente na ética de Platão, quando discorria a 
respeito da questão do bem e, mesmo em Aristóteles, ao introduzir a idéia de bom em substituição ao "bem" de Platão. Os economistas foram os primeiros a interessarem-se pelo termo valor, especificamente, entre eles, Adam Smith (Séc. XVIII) com a idéia de valor de troca, de uso.

No séc XIX, filósofos como Benthan e Stuart Mill, propuseram que a utilidade do ato poderia ser a medida da moralidade. O que fosse mais útil para o maior número de pessoas ou que proporcionasse a maior soma de felicidade e bem - estar deveria ser eleita como a ação mais justa. Isto põe o difícil problema da eleição de valor que deverá medir a moralidade dos atos. ${ }^{(7)}$

O termo valor é usado com significados diversos, é considerado como "tudo aquilo que de qualquer modo preencha uma carência humana...". (5)

Os valores não existem por si mesmos, pelo menos, neste mundo necessitam de um depositário. Aparecem como meras qualidades desses depositários. Não se pode identificar o valor com a qualidade da coisa. Uma qualidade faz parte da própria existência do objeto, ao passo que o valor refere-se sempre ao sujeito e sua relação com o objeto. ${ }^{(8)}$

O valor também pode ser visto como sendo algo que satisfaz a uma necessidade, "será valor tudo aquilo que for apropriado a satisfazer determinadas necessidades", embora isso não seja tudo. ${ }^{(8)}$ 
"O conceito de valor não pode ser rigorosamente definido. Pertence àqueles conceitos supremos como "ser", "existência" que não admitem definição, o que se pode fazer é uma clarificação ou compreensão do seu conteúdo". (6)

Diante desses conceitos, vale ressaltar que não implica compreender os valores nem agir, de acordo com eles, pois o conhecimento do valor causa uma experiência e, conseqüentemente, uma resposta positiva ou negativa, uma retificação do agir. ${ }^{(9)}$

A teoria dos valores parte do fenômeno valor, que é dado em nossa consciência dos valores, na vivência que se tem deles. Todos nós poderíamos valorar e não podemos deixar de faze-lo. Não é possível a vida sem proferir, constantemente, juízos de valor. É da essência do ser humano conhecer e querer, tanto quanto valorar. Nada podemos querer, senão, aquilo que, de qualquer maneira, nos pareça valioso e como tal digno de ser desejado. ${ }^{(6)}$

Experimentar a atitude de valorar é reconhecer alguma coisa como valioso, no sentido de sermos nós a atribuir-lhe um valor, julgando e apreciando, emitindo um juízo de valor.

A idéia de emitirmos juízos de valor, inicialmente, foi concebida por Aristóteles, o primeiro filósofo a entender que não basta que nossos atos éticos sejam valorosos, eles precisam ser observados e submetidos ao julgamento do "outro". Ele introduz a alteridade na ética e submete a possibilidade de sermos virtuosos ao julgo do "outro", só o 
outro é capaz de perceber nossas virtudes. Aristóteles fundamenta sua ética, portanto, no vinculo de dependência absoluta entre o eu e o outro. Vários outros filósofos, posteriormente, consolidaram este conceito, entre eles, Sartre.

Com a introdução da alteridade na construção dos conceitos sobre o agir ético, começa a fazer mais sentido o emprego do termo "valor" na ética, uma vez que exista em sua conceituação a idéia de que ele decorre do encontro daquilo que se mostra (supostamente onde há algo a ser valorado) com aquele que vê (alguém apto a perceber o valor), ou seja, não pode haver valor na ausência de um ou de outro.

Mas também não se deve pensar que, no domínio dos valores, é o indivíduo valorante que decide o que é valioso e não valioso “o sujeito não é a medida dos valores”, pois um juízo de valor aspira algo mais do que uma simples validade subjetiva para aquele que o emite.

No conceito de valor está incluído o da referência a um sujeito que valora, pois

o valor é sempre valor para alguém. Valor - pode dizer-se é a qualidade de uma coisa que só pode pertencer-lhe em função de um sujeito dotado com uma certa consciência capaz de a registrar". (6)

É considerado, também, como algo que está entre o sujeito e o objeto, não está nem no sujeito, nem no objeto. Quando se diz que um objeto vale algo, significa que aquele algo se refere ao 
julgamento que se faz do objeto, mas também não está somente no sujeito.

Ele é encontrado no ser que o sustenta ou nele é introduzido pela ação do homem. Por exemplo, na natureza, encontramos um valor espontâneo, e na arte um valor instaurado pela ação humana. O homem pode instaurar valor no concreto por meio de seu trabalho.

O valor nos compromete na medida que nos obriga a nos posicionarmos. O valor precisa do objeto para ser visto, ele não é o próprio objeto, mas refere-se a ele.

Esta característica fez com que surgissem duas correntes:

O subjetivismo, também chamado de psicologismo, reduz - valor de uma coisa a um estado psíquico subjetivo, porque, para existir, necessita da existência de determinadas reações psíquicas do sujeito individual com as quais se identifica: não se deseja o objeto porque vale, mas ele vale porque é desejado ou porque dele se necessita.

O objetivismo axiológico afirma que há objetos valiosos em si. O valor é objetivo porque sua existência e natureza são independentes do sujeito. Os valores estão em relação especial com as coisas reais e valiosas que designamos bens. Entretanto, eles são imutáveis, o que mudam são os bens, nos quais se realizam.

Em oposição tanto ao psicologismo como ao logicismo axiológico, Max Scheler desenvolveu uma filosofia dos valores que, pode 
ser considerada em função de uma ampliação do domínio do conhecimento que, até então, privilegiava os processos lógicointelectuais.

Para Scheler, havia um tipo de conhecimento cujos objetivos eram inacessíveis à razão: o conhecimento dos valores para o qual ele atribui a seu processo de apreensão um caráter fundamentalmente emocional. Scheler cita que os valores são revelados por meio da "intuição emocional", ou seja, de um "sentir emocional" que tem referência imediata com o objeto: é por meio dela que conhecemos os valores que se encontram nos objetos.

“Assim como apreendemos a sensação da cor no ato da visão, do mesmo modo, apreendemos os valores no ato do nosso sentimento".(6)

O fato dos valores serem captados pelo perceber emocional, não se pode afirmar que eles só existam na medida que se pode captá-los.

Segundo Scheler, a ausência do perceber sentimental não suprime o valor do ser, pois eles existem como realidades objetivas, que são independentes dos seres que os portam, do momento em que são captados ou de quem os capta, e podem ser apreendidos objetivamente. “Nisso consiste o fundamento da axiologia scheleriana: a objetividade dos valores".(9) 
É importante ressaltar que o sentir emocional não pode ser confundido com os estados emocionais, pois estes estão relacionados à vivência do estado, do prazer e desprazer; é desprovido de intencionalidade e refere-se de modo não imediato a seu objeto, já a intuição emocional é intencional, tem referência imediata na qual se revelam os valores, ou seja, a captação do estado. ${ }^{(10)}$

O conceito de um determinado valor não implica compreender nem agir, de acordo com ele, o conhecimento do valor exige em uma experiência e, conseqüentemente, uma resposta, faz com que se assuma diante dele uma escolha, mas, nunca a indiferença.

Esta indiferença seria a própria negação do valor, pois, dessa forma, os valores teriam como característica a polaridade, nunca um valor é positivo e negativo ao mesmo tempo. Em decorrência da polaridade, não há valor único.

Perante a enorme diversidade de valores, Max Scheler desenvolveu uma teoria de valores, na qual estes valores são hierarquizados em função de sua importância relativa, estabelecida não pela razão, mas, por um sentimento preferencial. Além disso, os valores encontram-se em uma relação de hierarquia que, segundo ele, é a priori e escalonada pelo ato de preferência - base dos juízos axiológicos. É no ato de preferir - intuitiva ou conscientemente, acompanhado de reflexão que se dá a superioridade de um valor. Apesar desse ato determinar a superioridade de um valor sobre o outro, Scheler desenvolveu ainda cinco critérios para indicar a hierarquia axiológica: 
- Durabilidade: os valores seriam mais elevados, conforme fosse sua duração, sendo os inferiores os mais transitórios e de menor duração, ou seja, os mais passageiros e mutáveis.

- Divisibilidade: são mais elevados quanto menos divisíveis forem os valores

- Fundamentalidade: o valor que serve de fundamento a outros, seria mais elevado do que os que nele se fundamentassem.

- Satisfação produzida: os valores seriam mais elevados quanto maior a satisfação que produzissem.

- Grau de relatividade: os valores não são relativos, mas sim, o conhecimento que temos deles; mais alto é um valor quanto menos relativo seja.

De acordo com estes critérios, Scheler propõe a ordem hierárquica dos valores, em cuja base encontram-se os valores inferiores, isto é, todos aqueles que estão ligados às necessidades cotidianas. No topo da pirâmide, os valores religiosos, considerados de natureza superior. Cada valor é ainda apresentado sob uma dupla natureza, a positiva e a negativa. Tal hierarquia foi, assim construída:

- Valores religiosos: exemplo sagrado/profano; divino/demoníaco;

- Valores espirituais que são divididos em:

- Valores intelectuais: exemplo conhecimento/erro; evidente/ provável; 
- Valores morais: exemplo bom/mau; justo/injusto; leal/desleal;

- Valores estéticos: exemplo belo/feio; harmonioso / desarmonioso;

- Valores vitais: exemplo são/doente; enérgico/inerte;

- Valores úteis: exemplo capaz/incapaz; caro/barato; abundante / escasso. 


\section{OBJ ETI VO}

Com base nos pressupostos teóricos sobre os valores apresentados e reiterando a tese, segundo a qual nosso agir consciente é, necessariamente, ético e sustenta-se em um sistema de valores, este estudo tem por objetivo:

$\checkmark$ Conhecer os valores que norteiam o agir do enfermeiro. 


\section{TRAJ ETÓRI A TEÓRI CA METODOLÓGI CA}

Para compreender os valores norteadores do agir do enfermeiro, buscou-se um método que fosse mais adequado a esse entendimento, desse modo, optou-se pela pesquisa qualitativa que trata a "respeito de como se interpretar o ser das coisas, sua verdade e, também, os modos escolhidos para perscrutar, delimitar e expressar esse ser e essa verdade".(11)

Tal tipo de pesquisa expressa uma verdade entre várias outras, seria um equívoco acreditar que só há uma perspectiva reconhecida e confiável para a compreensão da verdade, do real. Dessa forma, pode-se falar que essa perspectiva é relativa, "o reconhecimento da relatividade da perspectiva é simultaneamente e necessariamente, o reconhecimento da relatividade da verdade". ${ }^{(11)}$, pois esta tem a concepção do sujeito que a vê, que cria em sua interpretação um conjunto de significados que, por sua vez, também serão relativos.

A pesquisa qualitativa busca compreender o ser humano, situando-o como um ser integrante do universo, com o qual se encontra em constante relacionamento, além de estar imerso em uma teia de significados, que ele mesmo constrói, mas que também sofre um processo de transformação externa no intercâmbio com o meio e este, por sua vez, se transforma e, assim, reciprocamente. 
Compreender esse ser humano envolve o desvelar de um mundo possível, uma espécie de acontecimento que transcende o próprio objeto que se oferece à interpretação e às condições de intérprete e interpretado. $^{(12)}$

O objeto a ser pesquisado é uma verdade, a partir de uma perspectiva do sujeito. Essa verdade, embora relativa, é passível de ser apreendida tanto nas relações cotidianas como também nas científicas que constituem a pesquisa qualitativa.

Na relação com o mundo, o pesquisador estabelece um encontro com o outro, com falas e discursos singulares, por meio da tradução da experiência do outro, em um encontro de subjetividades.

Com o objetivo de compreender os significados e analisar esses significados no campo da linguagem, optou-se pela pesquisa qualitativa a partir da Hermenêutica, pois, por meio dela:

“Linguagem e significado estão relacionados simbioticamente. Dependemos da linguagem para significar nossos atos, dar sentido à nossa existência; é a linguagem que estabelece o domínio da interpretação. O significado resulta de um ato interpretativo, em busca da compreensão desde que se considere que o próprio processo de busca cria e recria algo novo pelo interprete".(13) 
Além disso,

“como seres humanos, estamos sempre envolvidos em gerar um sentido para nossas vidas, e fazemos isso interpretando a nós mesmos e ao mundo a nossa volta, dentro do nosso sistema de linguagem e dos campos de sentido em que vivemos. Daí a importância da linguagem, uma vez que sentido, compreensão e entendimento só podem se dar no campo definido por ela".(12)

A hermenêutica como arte e técnica da interpretação correta da linguagem que aborda textos, começa com o esforço dos gregos para preservar e compreender seus poetas, e desenvolve-se na tradição judaico-cristã de exegese das Sagradas Escrituras. A partir do Renascimento, fixam-se três tipos básicos de interpretação: hermenêutica teológica (sacra), filosófica-filológica (profana) e jurídica (júris). ${ }^{(14)}$

Scheleirmacher, teólogo, filólogo e filosofo alemão teve seus estudos de hermenêutica inseridos tanto na tradição exegética da teologia protestante, como no renascimento nos estudos de filologia clássica. Embora fosse uma técnica bastante antiga, foi com esse teólogo que recebeu um tratamento sistemático que a introduziu na ciência moderna. ${ }^{(14)}$

A hermenêutica refere-se à compreensão e interpretação. Assim, podemos dizer que os seres humanos são geradores de 
significados e que seu mundo é construído no intercâmbio entre as pessoas por meio de linguagem e, dessa forma, os significados podem ser compreendidos como um discurso decorrente do diálogo. Significado e linguagem envolvem uma relação simbiótica que não podemos abordar um sem nos referirmos ao outro. O significado implica um campo de sentido, que envolve uma abordagem interpretativa própria de uma ciência hermenêutica. ${ }^{(12)}$

Assim pensando, a autora referida, ressalta um ato de mediação entre um intérprete e um interpretado, ou seja, o significado não pode ser atribuído nem ao intérprete, nem ao interpretado, mas, ao resultado dessa intervenção, o significado resulta de um ato interpretativo. $^{(12)}$

Pode-se observar, ainda, que a compreensão dos significados pelo intérprete ocorre a partir de suas pré-estruturas de compreensão, o intérprete pertence a um determinado campo de conhecimento e de cultura, ele não chegou vazio onde se encontra, veio trabalhado, condicionado pelo ser histórico que é, ele dirige-se ao texto com seus preconceitos, prejulgamentos, questões e suposições, ocorre um diálogo perfeito entre o intérprete e a obra que Hans-Georg Gadamer denominou de fusão de horizontes. ${ }^{(12)}$

Para Gadamer, o significado é descoberto na distância da compreensão, mas decorre da participação na história efetiva, de modo que aquilo que se compreende vem a fazer sentido, baseado em um enlace circular com o que já sabemos. Nesse sentido, o autor refere-se a 
Heidegger retomando o conceito de círculo hermenêutico: “compreendemos só o que já sabemos".(12)

Assim, aquele que se propõe a compreender alguém, deve abrir-se para a escuta do outro, o que aponta para um mundo possível, mas isso só pode ser feito com base no horizonte significativo do ouvinte, parece que não há como compreender alguém, pertencendo ou não à nossa cultura, senão a partir de nossos próprios significados.

Gadamer considera como principal condição hermenêutica que algo precisa chamar nossa atenção para se começar a compreensão. A interpretação do significado de um texto verifica-se a partir do horizonte de compreensão. ${ }^{(12)}$

É importante também ressaltar que

“a apreensão do pensamento do outro, logo a compreensão correta do discurso alheio se realiza através da compreensão da linguagem em que ele expressou seu pensamento. Não há outra via de acesso ao que o outro quis dizer senão o seu discurso, ou seja, o seu uso da linguagem para expressar alguma coisa do ouvinte". (15)

O homem pode pensar e falar e poder falar significa: poder tornar visível pela sua fala, algo ausente, de tal modo que, também, um outro possa vê-lo. O homem pode comunicar tudo que pensa e, por essa capacidade de comunicação, os homens podem pensar o comum, ou seja, conceitos simples que tornam sua convivência possível. ${ }^{(16)}$ 
A compreensão não se dirige para o que está dentro ou detrás do discurso, mas, para um ponto de encontro no presente que aponta para algo que transcende o dito em uma espécie de referência virtual, para uma condição de mundo possível em um campo de consenso entre o mundo do intérprete e do interpretado. ${ }^{(12)}$

Para Gadamer, a interpretação "não é algo que ocorre na cabeça do intérprete, mas nesse interjogo dialógico entre esse cruzamento de horizontes. Assim, para esse filósofo compreender é sempre mais do que a mera recriação do significado de alguém. A compreensão envolve um projetar-se do intérprete sobre o objeto de sua compreensão, a partir de expectativas relacionadas a algum sentido" (12)

O autor citado considera que

“não existe um significado em si, passível de ser capturado de forma correta. O significado que surge da interpretação não é o significado verdadeiro, uma vez que o próprio processo de busca dá forma, reformula, cria e recria alguma coisa de novo pelo intérprete. O significado é uma decorrência da pré-compreensão do interprete, dentro dos limites e das condições práticas lingüísticas em que está envolvido". ${ }^{(12)}$

A hermenêutica possui alguns pressupostos metodológicos que foram adaptados e utilizados como norteadores para a interpretação das entrevistas desta pesquisa: 
a) o pesquisador precisa aclarar para si mesmo o contexto de seus entrevistados ou dos documentos a serem analisados;

b) o estudioso do texto (termo considerado no sentido amplo: relato, entrevista, história de vida, biografia, etc.) deve supor a respeito de todos os documentos, por mais obscuros que possam parecer à primeira vista, um teor de racionalidade e de responsabilidade que não Ihe permita duvidar;

c) o pesquisador só pode compreender o conteúdo significativo de um texto quando está em condições de tornar presentes as razões que o autor teria para elaborá-lo;

d) por outro lado, ao mesmo tempo, em que o autor busca entender o texto, precisa julgá-lo e tomar posição em relação ele. Compenetrar-se no fato de que no labor da interpretação não existe última palavra.

Vale justificar que a hermenêutica não apresenta de forma clara uma técnica para a análise dos dados coletados, portanto, para este estudo foram construídas as etapas para a análise com base em seus pressupostos teóricos e metodológicos, que são as seguintes:

- Leitura atenta e detalhada dos discursos dos sujeitos pesquisados;

- Anotação das idéias significativas que representam os valores; 
- Agrupamento dessas idéias por afinidade de significados;

- Identificação das categorias com base nesses significados;

- $\quad$ Análise dessas categorias sustentadas em vários autores.

\subsection{Local da pesquisa}

A escolha do local, o Hospital São Paulo, como campo para a coleta de dados baseou-se no fato da proximidade, facilidade de acesso e familiaridade da pesquisadora em relação ao local. Foram escolhidas unidades de internação clínica e cirúrgica, que são utilizadas como campo de estágio para os alunos do Curso de Graduação em Enfermagem da Universidade Federal de São Paulo (UNIFESP), na disciplina Enfermagem na Saúde do Adulto Institucionalizado.

Optou-se também por entrevistar enfermeiras que, prioritariamente, trabalham em unidades de internação porque esses locais parecem ser uma situação em que a relação humana é mais complexa, dada a quebra do cotidiano do paciente que se encontra em uma situação peculiar, que é a própria internação, e tem como conseqüência a necessidade de uma relação mais elaborada e a possibilidade dessa relação com o paciente influenciá-lo de modo mais marcante. 


\subsection{A participação dos sujeitos}

Participaram como sujeitos deste estudo oito enfermeiras. Não houve outro critério de inclusão, a não ser o fato de serem enfermeiras que atuam ou atuaram nas unidades de internação e terem aceito participar da pesquisa, depois de convidadas.

Vale ressaltar que o número de enfermeiras decorreu da utilização da técnica de esgotamento, recomendada na pesquisa qualitativa, que significa que os dados são coletados até as expressões e os significados tornarem-se repetitivos.

\subsection{A coleta de dados}

Após a aprovação do projeto pelo Comitê de Ética (Anexo 1), os sujeitos foram esclarecidos quanto aos objetivos, finalidades e aos itens do Termo de Consentimento Livre e Esclarecido (Anexo 2), a ser assinado, conforme preconizado na Resolução no 196/96 do Conselho Nacional de Saúde ${ }^{(17)}$, que versa sobre os aspectos éticos da pesquisa envolvendo seres humanos.

A coleta dos dados ocorreu nos meses de julho e agosto de 2002. 


\subsection{Entrevistas}

Tendo em mente o objetivo de apreender por meio da escuta atenta aquilo que o outro tem condições de narrar e a busca do significado no discurso, o método utilizado foi a entrevista semiestruturada.

Para a realização das entrevistas, foi feito um contato prévio com cada uma das enfermeiras, solicitando sua participação. Após o aceite, foi marcado o local e horário para a concretização das mesmas.

Com o objetivo de fazer um exercício da coleta de dados por meio de uma entrevista semi-estruturada, acreditou-se ser conveniente realizar uma entrevista "piloto", que foi feita pela orientadora deste trabalho, tendo a pesquisadora como observadora.

No momento das entrevistas, foi feito todo o esclarecimento a respeito da pesquisa e do termo de consentimento, que elas assinaram.

As entrevistas ocorreram na própria unidade, por opção das enfermeiras, em algum local que tivesse privacidade, essa escolha foi para que pudessem estar mais próximas, caso algum paciente ou funcionário solicitasse.

O roteiro da entrevista foi elaborado por questões norteadoras, abertas, com o objetivo de expressarem livremente sobre os aspectos abordados, mas, sem se desviar da finalidade do estudo. 
As entrevistas foram gravadas e transcritas integralmente.

As questões norteadoras foram:

Considere-se em seu cotidiano de trabalho, e nas relações que você estabelece nesse cotidiano, responda:

$\checkmark$ Quais são os valores, que você acredita, que sustentam seu agir assistencial?

$\checkmark$ O que são para você (os valores que foram citados)?

$\checkmark$ Como (os valores que foram citados) aparecem em seu agir cotidiano de trabalho?

Após a entrevista, foi solicitado a cada enfermeira o preenchimento de um questionário com a finalidade de circunstanciar e conhecê-las, e com isso apreender a relação que elas constroem em sua vida cotidiana para a possível compreensão da expressão dos valores que referiram (Anexo 3).

\subsection{A análise dos dados}

Com a finalidade de verificar o que os sujeitos queriam dizer em cada um dos seus discursos, são descritos, a seguir, os passos desenvolvidos para elaboração da análise deste trabalho: 
A transcrição das entrevistas e a leitura atenta do todo foram feitas, para que fosse possível familiarizar-se com os discursos.

Posteriormente, as entrevistas foram lidas separadamente e anotado o que as enfermeiras indicavam como valores, assim, ao final de cada uma delas foi possível apreender o que havia de significativo.

As idéias significativas assimiladas de cada entrevista foram agrupadas, formando as categorias.

Assim, com base nessas categorias a análise dos significados foi feita, conforme já descrito, que é apresentada com suas discussões e exemplificada com as falas das próprias enfermeiras. 


\section{APRESENTAÇÃO DOS RESULTADOS}

\subsection{CARACTERI ZAÇÃO DOS SUJ EITOS}

Acreditamos ser importante localizar e circunstanciar de forma breve algumas informações a respeito dos sujeitos deste estudo com o propósito de contribuir para a melhor apreensão dos conteúdos referentes aos valores propriamente ditos à rede de significados que se estabeleceu intrinsecamente entre eles e as demais coisas de seu mundo, definindo seus modos de agir e suas escolhas.

Em outros termos, partiu-se do pressuposto que dados relativos ao sujeito são elementos constitutivos de sua história pregressa e posterior e estes por sua vez, são, ao mesmo tempo, componentes estruturadores e estruturantes de nossos valores, de nossas crenças e do sistema de significados do qual fazem parte.

As informações foram obtidas por meio de um questionário (Anexo 3), conforme descrito na trajetória metodológica e são apresentados individualmente.

Após essa descrição, tendo como diretriz a questão norteadora "Quais são os valores que você acredita que norteiam o seu agir profissional", serão apresentadas as categorias formadas apoiadas 
nos núcleos de significados apreendidos nos discursos das enfermeiras, sujeitos deste trabalho.

\section{Entrevistada 1}

Idade 29 anos, concluiu a graduação em universidade particular. A origem de seus pais e avós é paulistana. Seus pai tem nível superior de instrução incompleto e a mãe completo. Sua crença religiosa é o espiritismo, mas não o freqüenta regularmente. Convive diariamente com os pais, marido e filha e relaciona-se, freqüentemente, com amigos e outras pessoas da área da enfermagem, suas atividades diárias, além do trabalho, são o curso de especialização e os serviços de casa. Atua na área assistencial.

Não freqüenta atividades em grupo, nem convive com as artes, faz leitura de revistas aos finais de semana, mas sem especificar o tipo. Além disso, ouve música diariamente.Sua experiência mais significativa é ser mãe, e os valores que embasam suas opções de vida são: a honestidade, lealdade, simplicidade, personalidade e respeito mútuo.

\section{Entrevistada 2}

Idade 27 anos, concluiu a graduação em universidade pública em São Paulo.

A origem do seu pai é paulista, mãe e avós alagoanos, avô paterno espanhol e avó carioca. O grau de instrução de seus pais é 1 o grau incompleto, profissão da mãe é do lar e do pai técnico em eletrônica, os avós paternos, sapateiro e costureira e maternos trabalhavam na roça.

A religião de seus pais é católica e ela não tem religião. Convive diariamente com pais e irmãos e relaciona-se, freqüentemente, com amigos e familiares. As atividades diárias, além do trabalho, são estudo, cuidados com a casa e, às vezes, sair com amigos. Atua na área assistencial. 
Uma vez por mês, freqüenta dois tipos de grupo relacionados à enfermagem, além das leituras diárias relacionadas à sua especialidade, lê romance, jornal e revista.

No convívio com as artes, freqüenta museu mensalmente e seu hobby é viajar, aproximadamente, uma a duas vezes por mês, pratica ginástica.

Possui como experiência significativa conhecer pessoas inesquecíveis e como valores que embasam suas opções de vida, viver bem, feliz, sabendo o que está fazendo.

\section{Entrevistada 3}

Idade 25 anos, concluiu o 2 o grau em colégio particular e a graduação em universidade pública.

A mãe e os avós maternos são cariocas, o pai e avós paternos, paulistas. Os pais e os avós possuem nível superior de instrução, sendo sua religião e dos pais católica praticante.

Convive diariamente com pessoas, em geral, do mesmo nível cultural e relaciona-se com freqüência com colegas enfermeiras e também com pessoas com nível cultural abaixo do seu.

Suas atividades diárias são o trabalho e o curso de especialização. Atua na área de ensino e assistência. Freqüenta atividades em grupo relacionadas ao curso de especialização, três vezes por semana. Faz leituras em geral, livros de auto-ajuda e específicos, três vezes por semana. Não tem convívio com as artes, nem hobby.

Apresenta como experiência significativa o fato de algumas vezes ter perdido a fé diante daquilo que parecia impossível de ser resolvido e, após algum tempo, ter sido solucionado e esclarecido.

Os valores que embasam suas opções de vida são valorizar a saúde, aproveitar o lado bom das situações e das pessoas.

\section{Entrevistada 4}

Idade 51 anos, concluiu a graduação em universidade pública em São Paulo. 
A origem de seus pais e avós é brasileira, a profissão de sua mãe é prendas domésticas e o pai é pecuarista. Grau de instrução de seus pais é 1 o grau, sua religião e dos pais é católica, não praticante.

Convive diariamente com os irmãos e não referiu com quem se relaciona com freqüência no âmbito social.

Apresenta como atividades diárias o trabalho, o curso de inglês e a academia de ginástica, não freqüenta atividades em grupo, diariamente, faz leituras de revistas semanais e livros. No convívio com artes freqüenta cinema. Não cita ter hobby, nem relata experiência significativa que tenha vivido. Os valores que embasam suas opções de vida são os que constam na entrevista.

\section{Entrevistada 5}

Idade 37 anos, concluiu a graduação em universidade pública em São Paulo. Seus pais e avós são de origem japonesa. Os pais são comerciantes aposentados, tendo como nível de instrução o 1 o grau.

A religião: o pai e avós budistas, a mãe, espírita e budista.

Convive diariamente com marido e filho e relaciona-se, com freqüência, com alguns amigos do trabalho e familiares.

Suas atividades diárias são: o trabalho, atividades domésticas, curso de inglês e atividades científicas. Atua na área assistencial, freqüenta atividade em grupo relacionada à enfermagem, uma vez por semana.

Faz leituras científicas, religiosas, notícias, etc., regularmente. No convívio com as artes, freqüenta teatro esporadicamente. Tem como hobby natação e tênis que pouco pratica. É católica não praticante, sua experiência significativa foi a adaptação no J apão.

Os valores que embasam sua opção de vida são: liberdade, confiança, honestidade, amor e união.

\section{Entrevistada 6}

I dade 26 anos, concluiu o 2으 grau em escola particular e a graduação em universidade pública em São Paulo. 
Seus pais são de origem brasileira, e os avós italianos, austríacos, portugueses e brasileiros. O pai é engenheiro e sua mãe, dona de casa. 0 avô paterno policial e a avó, do lar. O avô materno fiscal e avó, do lar. O grau de instrução de seu pai é superior e da mãe, 2 o grau.

A religião de seus pais e avós é católica. Convive diariamente com o pai, a mãe e a irmã e relaciona-se com freqüência com amigos do trabalho.

O trabalho é sua atividade diária, atua na área assistencial, não freqüenta atividades em grupo. Faz leituras de revistas e livros de autoajuda e misticismo, duas a três vezes semanais.

Não refere convívio com as artes, seu hobby é leitura e assistir a documentários na TV todas as noites, a religião é o espiritismo, mas, não é praticante.

A experiência significativa foi uma viagem para o exterior, assim, o conhecimento de outra cultura. Os valores que embasam sua opção de vida são aqueles que executa como gostaria que fizessem com ela, além de evitar ao máximo prejudicar alguém.

\section{Entrevistada 7}

Idade 41 anos, concluiu a graduação em universidade pública no Mato Grosso. A origem de seus pais é brasileira e dos avós, italianos. A profissão dos pais e avós é de agricultores, os pais possuem nível de instrução primário e os avós, primário incompleto.

A religião dos pais e avós é católica. Convive diariamente com a filha e o marido, relaciona-se freqüentemente, com os profissionais da área da saúde, suas atividades diárias são o trabalho e as ligadas ao cuidar da casa.

Atua na área não assistencial, não freqüenta atividades em grupo, nem refere fazer leituras, nem ter hobby.

Não tem convívio com artes, é católica não praticante.

A experiência significativa que viveu, foi a maternidade, o valor que embasa sua opção de vida, é a família. 


\section{Entrevistada 8}

I dade 33 anos, concluiu o 2ㅇ grau em escola particular e a graduação em universidade particular em outra cidade.

A origem de seus pais é brasileira e os avós italianos e espanhóis. Seus pais são aposentados e têm o 2 o grau completo.

Os pais e avós são católicos. Não convive com ninguém da família diariamente por residirem em outra cidade. Com freqüência, relaciona-se com o namorado e as amigas, tendo como atividade diária o trabalho.

Atua na área assistencial. Não freqüenta atividades em grupo, faz diversas leituras diárias, não tem convívio com as artes, seu hobby é música de diversos tipos diariamente.

A sua religião é o espiritismo, é praticante, a experiência significativa foi o nascimento do primeiro sobrinho.

Os valores que embasam suas opções de vida são: a lealdade e a consciência tranqüila de realizar sempre o melhor que pode.

Observa-se que neste grupo de enfermeiras, há pouca amplitude e intimidade com o mundo simbólico e um envolvimento maior com o mundo prático e concreto, presente em suas atividades diárias.

Aparentemente, isso pode significar um interesse mais focado no mundo concreto e, conseqüentemente, maior habilidade para abordar temas também concretos e mais bem definidos no que tange ao julgamento de valor, qualidade e normalidade. Temas mais afetos ao mundo simbólico que demandem abstrações, reflexões e julgamentos particulares podem estar mais distanciados de seus repertórios. Essa suposição poderá ser reiterada quando forem tratadas as questões relacionadas aos valores explicitados pelo grupo e seus significados, conforme será apresentado nas categorias descritas a seguir. 


\subsection{APRESENTAÇÃO E DI SCUSSÃO DAS CATEGORI AS}

\section{CATEGORI A 1. CONHECI MENTO COMO MEIO DE OBTER COMPETÊNCI A NO AGI R E ASSEGURAR O PODER}

Esta categoria diz respeito à questão de como o agir profissional das enfermeiras está voltado ao conhecimento como suporte para o cuidar cotidiano, analisando os diferentes tipos de conhecimento a que se referem e a função que parece ter na busca dessas enfermeiras por outros valores que se manifestam, como a competência, segurança e poder.

Pela leitura dos discursos, foi possível apreender que, para estas profissionais, o conhecimento é um dos valores de grande importância para seu agir profissional. Embora, algumas vezes, nestes discursos elas façam referência a conhecimentos genéricos, mas estão referindo-se a conhecimentos científicos.

Estes conhecimentos parecem ser uma apreensão aprofundada de determinado conhecimento adquirido por meio da observação de fenômenos, fatos ou pesquisas.

Foi possível perceber ainda que o conhecimento científico confere a elas segurança na tomada de decisões, tanto com relação ao paciente quanto com sua equipe ou, ainda, em relação às atividades 
administrativas da própria unidade. Parece ser a condição necessária para que tenham iniciativa para assumir condutas e atitudes.

Aparentemente, conhecimento traz para essas enfermeiras a certeza de que a forma como estão agindo, é a correta e mais adequada. Ele embasa suas habilidades e confere-Ihes domínio para agirem de forma cientificamente consensual.

Além disso, o conhecimento parece atribuir-lhes possibilidades de caracterizarem-se como profissional específico, diferenciando-as inclusive dos demais membros da equipe e, também, validando uma hierarquia profissional.

As enfermeiras relatam que o conhecimento é necessário para a vida, mas, em sua profissão a importância é ainda maior, pois, caso contrário não teriam condições nem segurança para desempenharem adequadamente as funções.

Assim, parece que elas buscam no saber um meio para atingir alguns fins: a capacidade de tomar decisões, habilidades, iniciativa, responsabilidade e segurança (para este conjunto usaremos o termo competência, que será abordado, posteriormente). Além da competência parece também que buscam assegurar o poder.

E2 "...acho que, em primeiro lugar, nosso conhecimento; acho que você tem que ter confecimento científico suficiente para você poder tomar alguma decisão, ter iniciativa de tomar algumas condutas que sejam importantes, ter 
responsabilidade no que você faz, para não fazer nada que não tenha certeza do que está fazendo...”.

E8 "...ele é o que me diferencia enquanto profissional enfermeira... porque através do meu confecimento, do meu embasamento que eu vou me posicionar como profissional...".

E8 “...certeza que a atitude que você tomou quando cuidou de alguém, era a melhor que você podia ter feito...".

E8 “... habilidade também envolve o conhecimento, então é você saber o que está fazendo e porque está fazendo...".

E4 “...acho que, na vida como um todo, você precisa de confecimento de como viver, mas acho que assim ... pesa muito na profissão, acho que se você ... qualquer profissão que você vai ter, se você não tiver uma, não adquirir um conhecimento para desempenhar aquela função, acho que você não consegue desempenhar bem a sua função ... porque você não está confiante naquilo que você vai fazer...".

Ao explorarmos as finalidades do conhecimento científico para estas enfermeiras, é possível perceber que manifestam essas finalidades e as concepções diversas em relação ao que seja conhecimento científico. Em alguns momentos, suas falas denunciam evidências de que utilizam o termo em questão com base no conceito clássico de conhecimento científico, ou seja, naquele que constrói verdades apoiadas na aproximação de axiomas teóricos com observações sistematizadas e reiteradas de um fenômeno controlado. 
Em outras falas, as enfermeiras deixam transparecer as suas experiências particulares, não sistematizadas, ou seja, o conhecimento adquirido empiricamente que pode ser o meio, pelo qual adquirem confiança em seu agir correto e seguro, ou seja, "confio no que vejo" sem grandes preocupações para sistematizar e controlar o que está sendo visto.

A inter-relação dinâmica entre esses dois conhecimentos é desejável e até necessária para que seja possível questionar verdades, reiterá-las ou refutá-las para refinar os conceitos. No caso particular destas enfermeiras, chama a atenção a aparente desinformação do papel de cada um desses conhecimentos e de suas etapas (sempre submetidos a métodos) no processo de construção de verdades. Mais do que isso, a desinformação que, aparentemente, demonstram, parece indicar que sequer reconhecem que se trata de conhecimentos diferentes.

E4 "Eu só confio naquilo que eu vejo, né? E, assim, para eu desenvolver meu trabalho é preciso dominar aquilo que eu estou fazendo, tem que estar consciente, tem que saber aquilo que eu vou fazer, tem que ter certeza que aquilo que eu estou fazendo, que eu estou agindo de acordo com aquilo que, pelo menos, é cientificamente correto para ser aceito...".

E2 "Iniciativa, é assim, é você ter iniciativa mesmo de você estar tomando uma conduta em relação, por exemplo, na parte não só do paciente, mas de estar mostrando alguma coisa que você percebe, para o medico para poder tomar uma conduta mais, às vezes é uma coisa pequena que ninguém... passa desapercebido...". 
Outro tipo de conhecimento que, também, foi possível apreender nos discursos, é o dogmático, ou seja, aquele baseado na crença.

As enfermeiras crêem que esses conhecimentos são empregados em sua prática diária, por meio de certos procedimentos técnico-científicos que podem trazer certezas que a própria ciência não é capaz de Ihes conferir. Elas precisam ter garantias de qualidade e evitar complicações, é a crença de que se está sempre fazendo o melhor para o paciente, que suas atitudes ao cuidar foram as mais adequadas.

E8 “...certeza que a atitude que você tomou quando cuidou de alguém, era a methor que você podia ter feito...".

E7 “... por exemplo, se vai fazer uma cirurgia, eu tenho certeza que a caixa está estéril, que a caixa está limpa que esse paciente vai ter uma segurança, no propósito dele; que ele veio no hospital ser operado, então ele vai ter um material em ordem de acordo, para ele ser operado; que não vai causar infecção, que não vai The causar problemas, entendeu?”.

E8 "...é sempre a certeza, a consciência tranqüila de você fazer o melhor que pode, isso que é um pouco relativo, mas é esgotar suas possibilidades de saber conseguir aplicar no dia-a-dia ....".

Resgatando as finalidades do conhecimento científico, expressas pelas enfermeiras deste estudo, e já apresentadas na página 38, podemos discriminar dois núcleos de significados: 
- O comando da equipe visando a assegurar o poder por meio da liderança, controle, direcionamento e autoridade

- Competências voltadas para o assistir e cuidar do paciente;

Um terceiro núcleo poderia ser delineado com base nas finalidades apresentadas e que estaria relacionado a estratégias de manejo dos próprios afetos, dos mecanismos de enfrentamento de situações não confortáveis, ou ainda, de defesas contra ansiedades, medos e angústias, dentre outros afetos desagradáveis. Esta vertente, no entanto, não será trabalhada como tal, em primeiro lugar, porque permeia todas as outras e os outros valores aqui apresentados; em segundo lugar, porque sua análise exigiria um referencial teórico derivado basicamente da psicologia o que desviaria do foco privilegiado neste trabalho.

Vale esclarecer que, nesse momento, será apresentado apenas o núcleo referente ao comando da equipe, uma vez que o outro núcleo aparecerá adiante.

Parece que, por meio do conhecimento, as enfermeiras buscam assegurar o poder que a hierarquia formal institucional Ihes atribui e melhor controlar e direcionar sua equipe. A autoridade também é importante para elas, mas, para comandar e liderar a equipe, não permitindo que os funcionários assumam responsabilidades, façam escolhas, pois , neste caso, perderiam o controle da situação. 
E2 "...acho assim, a cara de uma enfermaria é espelho do enfermeiro, porque assim os auxiliares não vão tomar conta do que você deve tomar, então se eles começam a tomar é porque você não tem mais esta autoridade, esta Ciderança toda. Acho que vira uma grande bagunça...".

E2 "... e ter assim o máximo da autoridade, de liderança e até autoridade, liderança para poder é comandar, direcionar sua equipe, porque você não faz nada sozinho...".

E2 "Então na autoridade e liderança em relação às condutas que você vai passar aos auxiliares, para poder ter assim um bom retorno, acho que tudo está meio ligado: a responsabilidade, o conhecimento, tudo. Quando você demonstra isso você está liderando eles, eles, então, vão fazer assim, como uma extensão do seu braço, vão fazer corretamente o que você pediu...".

Diante dos dados encontrados neste estudo, referentes ao conhecimento cientifico e com o intuito de elucidar significados possíveis nas falas encontradas nos discursos, vamos discuti-los tomando como ponto de partida a evolução histórica da ciência e do conhecimento.

$\mathrm{Na}$ época Clássica, o conhecimento não tinha como objetivo o domínio ou a transformação da natureza para fins específicos, mas tratava-se de uma forma de compreender e sintonizar-se com a cosmologia e a divindade. O saber apoiava-se em procedimentos de dedução discursiva. Durante a Idade Média, estava subordinado à filosofia e esta à teologia, portanto, era em Deus que se procurava a 
finalidade e o sentido de tudo o que existia, tendo como método o silogismo discursivo. ${ }^{(18)}$

Durante a época Moderna (séc XVI e XVII), preparada pelo Renascimento, começaram a ser valorizadas as observações diretas, a experimentação e a tecnologia. Desenvolveu-se uma visão mecanicista do Universo e a ciência propriamente dita. Na época, o saber passa a ser derivado da filosofia e não mais a própria filosofia, a natureza é vista como uma máquina e, como tal, os processos que nela ocorrem são vistos, como estando submetidos a leis matemáticas imutáveis e a encadeamentos causais.

Nessa fase, a linguagem matemática adquiriu consistência, pois permite atingir um raciocínio lógico, por meio da visualização que a linguagem discursiva não é capaz. Difunde-se a crença na verdade absoluta do conhecimento científico, que caminhava para a resolução de todos os enigmas do universo. ${ }^{(18)}$

O surgimento do Positivismo no séc. XIX, como uma corrente filosófica, vem reforçar a idéia de que o único conhecimento é o da ciência, baseando-se nas observações de fatos, ou seja, aquilo que é observável e submetido à experimentação, poderá tornar-se ciência, rejeitando qualquer explicação sobre as coisas que ultrapassassem a dimensão física. Estes princípios contribuíram para que se difundissem mitos como, por exemplo:

- que o conhecimento científico é o único e verdadeiro; 
- o desenvolvimento da ciência e da tecnologia é o único, e poderá conduzir a humanidade a um estado superior de perfeição, e o cientista era encarado como alguém, acima dos interesses particulares, unicamente devotado ao saber pelo saber;

- a resolução dos problemas da humanidade passa por confiar o poder a especialistas nas diversas áreas do conhecimento técnico e científico.

Assim, a idéia de que o conhecimento científico traria a certeza no agir correto e verdadeiro, a ciência como verdade segura e irrefutável, como é relatado pelas enfermeiras deste estudo, é uma idéia gerada no início da modernidade (século XVI) e consolidada no positivismo do século XIX, quando se difunde e reforça-se a crença na verdade absoluta atingida por meio do conhecimento científico que, para muitos, é a única espécie de conhecimento aceitável.

Mesmo aos neopositivistas da época Contemporânea, o conhecimento científico começa a deixar de ser visto como verdade absoluta e, muitos mitos envolvidos em torno da ciência do século XIX são abandonados.

No século $X X$, introduz-se a idéia de incertezas e probabilidades, reforçada pelos conceitos de Popper que demonstrou que toda ciência é baseada em conjecturas, em hipóteses que tentamos confirmar, mas também refutar. A ciência não é verdadeira, porém, 
conjecturável, "uma experiência cujo resultado é previsto por uma teoria, não prova a exatidão dessa teoria, mas se limita a não refutar".(18)

Ainda para Popper, a ciência precisa buscar o contraexemplo para obter a melhoria, o progresso e aprimoramento da teoria. É necessário formular as teorias não partindo de enunciados singulares e, por meio de indução, conseguir leis universais, mas iniciando na observação dos enunciados singulares pela imaginação. Para ele, quanto mais a ciência é refutável, mais será confiável. ${ }^{(19)}$ 
Para Chalmers, ${ }^{(20)}$

“o conhecimento científico não é conhecimento comprovado, mas representa conhecimento que é, provavelmente, verdadeiro, quanto maior for o número de observações formando a base de uma indução e maior a variedade de condições sob as quais essas observações são feitas, maior será a probabilidade de que as generalizações resultantes sejam verdadeiras".

O conhecimento científico é o único meio de se obter a verdade, e essa verdade científica é absoluta e irrefutável, ainda hoje, parece estar presente no pensamento de vários profissionais tanto nas instituições de ensino como de prática. Aparentemente, é esse conhecimento que as enfermeiras parecem referir-se neste estudo.

A apreensão desses conhecimentos pelas enfermeiras da pesquisa pode remeter-nos à evolução das práticas de saúde e da enfermagem propriamente dita.

No que diz respeito às práticas de saúde, antes mística e sacerdotal, no período hipocrático (final do século $V$ e início do século IV a.C.), passam a se basear, essencialmente, na experiência, no conhecimento da natureza e no raciocínio lógico, desencadeando uma relação de causa e efeito para as doenças e na especulação filosófica fundamentada na investigação livre e na observação dos fenômenos, limitada pela ausência quase total dos conhecimentos 
anatomofisiológicos. Esse período, dissociando-se a arte de curar dos preceitos místicos e sacerdotais, utiliza o método indutivo, da inspeção e da observação. Estes conceitos correspondem às idéias da época Clássica. ${ }^{(21)}$

Quanto às praticas de enfermagem, é a partir do aparecimento das ordens religiosas (primeiros séculos do período cristão) em razão da forte motivação cristã que movia as mulheres para a caridade, a proteção e a assistência aos enfermos começam a aparecer como uma prática leiga e desvinculada de conhecimentos científicos. A moral e a conduta eram mantidas sob rígidas regras nos grupos de jovens que se submetiam aos treinamentos de Enfermagem nos conventos, com um ensino essencialmente prático e não sistematizado. A esse tipo de vida, acorreram sobretudo as mulheres virgens e as viúvas e, como fundadoras dos monastérios femininos, as damas de grande influência na sociedade, vindas do poder e da nobreza. ${ }^{(21)}$

Por muitos séculos, a enfermagem foi praticada por religiosas e abnegadas mulheres que dedicavam suas vidas a assistência aos pobres e doentes. As atividades eram centradas no fazer manual e os conhecimentos transmitidos por informações a respeito das práticas vivenciadas. Predominaram as ações de saúde caseiras e populares com forte conotação mística sob a indução dos sentimentos de amor ao próximo e de caridade cristã.

Isso nos mostra a adequação ao conhecimento da época (Idade Média), na qual o saber estava vinculado a Deus. Assim, as 
pessoas pela fé cristã, voltaram suas vidas para a prática da caridade, assistindo os pobres e enfermos, manifestando um saber e uma prática dogmática.

Nesse período, os valores foram aos poucos legitimados e aceitos pela sociedade com características inerentes à enfermagem. A abnegação, o espírito de servir, obediência e outros atributos vieram consolidar-se como herança dessa época remota, dando à enfermagem não uma conotação de prática profissional, mas, de sacerdócio.

Na Renascença (século XVI), a enfermagem sofreu todas as conseqüências dos movimentos religiosos. Enclausurada nos hospitais religiosos, permaneceu empírica e desarticulada, vindo a desagregar-se ainda mais a partir da Reforma Religiosa e da Inquisição. Na época, muitos hospitais cristãos foram fechados e as religiosas que cuidavam dos doentes expulsas, sendo substituídas por mulheres de baixo nível moral e social. ${ }^{(21)}$

O modelo de saúde era dirigido ao atendimento das necessidades emergenciais do momento histórico, após muitas mudanças geradas pela Revolução Industrial, aliadas a interesses políticos, ocorreu uma reorganização da instituição hospitalar, na qual é possível encontrar as raízes do processo de disciplinarização e seus reflexos no horizonte da enfermagem.

É nesse cenário que a Enfermagem Moderna passa a atuar, quando Florence Nightingale é convidada pelo 
Ministro da Guerra da Inglaterra para trabalhar junto aos soldados feridos em combate na Guerra da Criméia (18541856). ${ }^{(21)}$

Florence fazia parte da elite econômica e social e era amparada pelo poder político, pois já possuía algum conhecimento de enfermagem, foi a precursora dessa nova enfermagem que se encontrava vinculada à política e à ideologia da sociedade capitalista.

As concepções teórico-filosóficas desenvolvidas por Florence apoiaram-se em observações sistematizadas e registros estáticos, vindos da sua experiência prática no cuidado aos doentes.

Assim, a enfermagem deixa de ser uma atividade empírica, desvinculada do saber especializado, mas, como uma ocupação assalariada, atendendo as necessidades de mão de obra nos hospitais, constituindo-se como uma prática social institucionalizada e específica. Estas práticas eram desenvolvidas por duas categorias distintas de enfermeiras as "ladies" que vinham da classe social mais elevada e que desempenhavam as funções intelectuais e as "nurses" que pertenciam aos níveis sociais mais baixos e que, sob direção das primeiras, desenvolviam o trabalho determinado por elas, ou seja, os cuidados e procedimentos com o paciente.

Assim, o saber foi sendo construído e um corpo de conhecimentos foi, gradualmente, sendo desenvolvido e expandido, com o suporte de outras ciências. 
A ciência da enfermagem utilizou as observações sistematizadas e confrontou-se com outras ciências para que fosse possível justificar em que condições ou circunstâncias aquelas observações aplicar-se-iam.

E assim, durante muito tempo, o método indutivo foi usado como uma forma de conhecimento, mas, não o conhecimento científico, pois para que ele se tornasse científico, foi necessário vinculálo a uma teoria.

Uma outra questão importante que emergiu neste trabalho, foi a utilização do conhecimento dogmático que confere às enfermeiras deste estudo a certeza e a segurança do agir correto, que foram a base do saber na Idade Média, que trazia como característica da época a abnegação e a prática da caridade. Aparentemente, estes são princípios que, até hoje, fundamentam o saber e a prática da enfermagem.

Neste grupo, podemos observar que, aparentemente, há indícios de que essas enfermeiras possuem conhecimento desatualizado no sentido de se basearem em verdades antigas, ou seja, conceitos que correspondiam à Idade Média ou ao Positivismo no início do século XIX, e equivocado no sentido de não compreenderem adequadamente o saber atual.

Em nossa cultura e no âmbito da profissão de enfermagem, certas crenças são aceitas como verdades, sendo muitas 
perguntas e problemas resolvidos baseados nestas crenças. Se por um lado, elas se constituem em uma base de conhecimentos; por outro, podem trazer alguns equívocos à indagação humana, porque muitas dessas crenças encontram-se tão arraigadas à nossa cultura que sua validade ou utilidade jamais foram desafiadas ou avaliadas. ${ }^{(22)}$

De certa forma, é o que observamos na fala dessas enfermeiras quando relatam suas "certezas". Estas afirmações, por não terem a possibilidade de serem refutadas, caracterizam-se como dogmáticas, e “o verdadeiro espírito cientifico consiste em justamente não dogmatizar os resultados de uma pesquisa, mas tratá-los como eternas hipóteses que merecem constantes investigações". (23)

Assim, a fala das enfermeiras anuncia a crença de usarem conhecimentos científicos, empíricos e dogmáticos, a importância em se saber qual o conhecimento utilizado está no fato do hospital ter como base, como valor, o conhecimento científico. No entanto, pela falta de domínio, por parte das enfermeiras saber a respeito desses conhecimentos ocorre uma confusão entre eles e, isso pode afetar a própria qualidade da assistência prestada e, sobretudo, numa conduta não científica, pode tornar seu agir vulnerável e acabar abalando aquilo que parecem buscar que são a competência e o poder.

O conhecimento utilizado por estas enfermeiras, além de Ihes conferir poder, pode assegurar a ilusão de isenção da responsabilidade, pois a opção não é do enfermeiro, mas, da própria ciência, ou seja, elas acreditam que a ciência substitui sua 
responsabilidade na tomada de decisão, e isso lhes poderá conferir a segurança em seu agir profissional.

A associação entre conhecimento e poder não é recente nem restrita a estas enfermeiras. Francis Bacon, no séc XVI, já anunciava essa idéia quando dizia que "saber é poder". ${ }^{(24)}$

A respeito da relação saber e poder, as enfermeiras de um estudo relatam que:

as relações de poder manifestam-se, entre outras formas, nas relações entre o enfermeiro e equipe de enfermagem. Essas relações são mais explícitas devido à existência de uma hierarquia. O enfermeiro com base no conhecimento técnico centraliza, julga e direciona as ações. As relações de poder baseiam-se no conhecimento, vivência e também na experiência dos superiores hierárquicos. As relações de poder, no departamento de enfermagem, ocorrem de maneira participativa prevalecendo as decisões de quem detém maior conhecimento específico. $^{(25)}$

A relação saber / poder também pode estar associada a um dos mitos do conhecimento científico, originados no Positivismo do século XIX, que "a resolução dos problemas da humanidade passa por confiar o poder a especialistas nas diversas áreas do conhecimento técnico e científico". (18) 
Pela fala das enfermeiras, podemos perceber que o poder, a liderança, a autoridade são as finalidades que elas acreditam conseguir, quando possuem conhecimento, embora o cargo exercido na instituição já Ihes confira esse "poder". É interessante perceber que, essas profissionais, o utilizam como uma forma de controle e dominação.

Embora façam menção ter como foco de seu agir o paciente, também, relatam sobre o conhecimento científico voltado prioritariamente ao comando e direção da equipe.

Nos discursos apresentados, é possível observar um certo autoritarismo com o funcionário ou uma desconsideração pela pessoa de seu funcionário e, mesmo de seu paciente, pois parece que, quando elas relatam "a cara de uma enfermaria é o espelho do enfermeiro", ou ainda, “eles vão fazer assim, como a extensão do seu braço", não levam em consideração as outras pessoas que fazem parte dessa enfermaria, a equipe e o próprio paciente.

Ao contrário do que as enfermeiras do estudo relatam, $\operatorname{Arendt}^{(26)}$ formula o seguinte conceito:

o poder corresponde à habilidade humana, não apenas para agir, mas para agir em conjunto. O poder nunca é propriedade de um indivíduo; pertence a um grupo e permanece em existência apenas na medida em que o grupo conserva-se unido. 
Com relação à autoridade também expressa pelas enfermeiras como sinônimo de poder, a autora citada refere que

[...] visto que a autoridade sempre exige obediência, ela é comumente confundida com alguma forma de poder ou violência. Contudo, a autoridade exclui a utilização de meios externos de coerção; onde a força é usada, a autoridade em si mesmo fracassou. [...] Se a autoridade deve ser definida de alguma forma, deve sê-lo, então, tanto em contraposição à coerção pela força como à persuasão através dos argumentos. A relação autoritária entre o que manda e o que obedece não se assenta nem na razão comum nem no poder do que manda; o que eles possuem em comum é a própria hierarquia, cujo direito e legitimidade ambos reconhecem e na qual ambos tem seu lugar estável predeterminado. ${ }^{(27)}$

Assim, observamos que a autoridade, segundo a autora, aplica-se a idéias e conceitos e não a comportamentos, pois a autoridade direcionada a comportamentos é um exercício da autoridade disciplinadora, ou seja, poder.

Além das finalidades do conhecimento que levam essas enfermeiras a buscarem o poder, há também um objetivo procurar a competência. Para Perrenoud ${ }^{(28)}$, há uma relação íntima entre conhecimento e competência quando conceitua a competência como a 
“capacidade de agir eficazmente em determinado tipo de situação apoiada em conhecimentos, mas sem limitar-se a eles".

A não limitação aos conteúdos vincula-se à capacidade do indivíduo competente articular, integrar e mobilizar conceitos, além de unir a sua ação um comportamento ético e moral condizente com os princípios de cidadania. ${ }^{(29)}$

O conhecimento está intimamente ligado a competência. Para Resende ${ }^{(30)}$ “... quem tem mais conhecimento é, potencialmente, mais competente", porém Domenico ${ }^{(29)}$ relata que “... o conhecimento é necessário, mas, não suficiente para que as competências existam".

O conhecimento é uma ferramenta importante da competência, porém apenas detê-lo, não assegura uma ação competente, também, a capacidade (e a coragem) para inovar associada a outras habilidades cognitivas e psico-afetivas comportamentais configuram o perfil do indivíduo competente. As competências manifestadas em diferentes ações como: construir uma hipótese e verificá-la, argumentar sobre o texto lido, resolver um problema clínico, não são em si, conhecimentos; elas "utilizam, integram ou mobilizam tais conhecimentos". ${ }^{(28,29)}$

Diante do que foi exposto, vale ressaltar que a autoridade é, naturalmente construída, não pode ser buscada ou imposta, pois se assim o for, será considerada violência, ou seja, poder. 
É interessante observar que o conhecimento parece não ser compreendido por estas enfermeiras, como capaz de Ihes conceder a autoridade ou liderança conquistada na relação face a face, característica de quem administra o conhecimento com competência e autoridade. Esta seria uma das possibilidades das enfermeiras sobreporem-se à autoridade hierárquica e lidarem com as questões de seu trabalho em uma outra esfera: da construção, conquista, transformação e crescimento.

\section{CATEGORI A 2.}

\section{OS VALORES CONSTITUTIVOS DO CUI DAR}

Esta categoria aborda valores apontados pelas enfermeiras deste estudo como importantes no cuidado que prestam ao paciente.

Relatam que, para atuação profissional, é importante levar em consideração não só a esfera técnica voltada para o corpo, mas também, a psicológica e social do paciente e, com isso, valorizar o ser humano como pessoa, ver a utilidade de suas ações na assistência ao paciente, tentando percebê-lo como um todo, respeitando e colocando-se no lugar da pessoa, além de lhe proporcionar um atendimento que elas nomeiam como humanizado. 
Nos depoimentos relativos aos valores constitutivos do cuidado, buscou-se definir os valores que apontassem para a finalidade ética desse cuidado. Estes valores foram identificados nas falas e constituíram-se nos seguintes núcleos de significado: a valorização do ser humano, o ser humano como um todo, a utilidade de suas ações, o respeito, o atendimento humanizado, o atendimento das necessidades do paciente e a empatia, que serão descritos a seguir.

A valorização do ser humano é o principal valor para a enfermeira em sua assistência ao paciente, que é definido por elas, como um sentimento de solidariedade de ajudar a pessoa que adoeceu a recuperar sua saúde. Esta ajuda pode ocorrer pelo levantamento do diagnóstico e dos problemas de enfermagem.

E5 "... eu acho que assim, na assistência, principalmente a valorização do ser humano como pessoa em primeiro lugar, né?".

E5 “... essa valorização do ser humano... a pessoa, assim, que está... adoeceu agora, e que a gente precisa melhorar... ajudar; é uma forma de ajudar eu acho. É um sentimento de solidariedade de estar ajudando a pessoa, de estar prestando aquela assistência que ela está precisando naquele momento. Então, receber aquela pessoa; poder analisar o quê que ela está passando agora e diagnosticar, né? Problema de enfermagem e estar prestando essa assistência , né? Então .... é uma forma de realmente ajudar ela, de melhorar a saúde dela, né? De estar ajudando a ... a melhorar a saúde naquela doença que ela está passando agora, né? Então é realmente...é aquele sentimento de 
estar ajudando mesmo, a enfermagem, eu acho; de estar prestando assistência para melhorar, né?

Elas também relatam acreditar no atendimento do ser humano como um todo que, para elas, é considerar mais "a parte psicológica e sentimental do paciente". Aparentemente, dão destaque a “essas partes psicológica e sentimental", uma vez que a técnica acaba por ser adquirida naturalmente com o exercício prático.

Na leitura dos depoimentos chama a atenção que, apesar de relatarem acreditar no atendimento do paciente como um todo, essas enfermeiras utilizam-se do termo "parte" para se referirem ao foco de atenção que pretendem abordar no paciente, tais como: "parte psicológica, parte social, etc. Mesmo que no sentido literal a intenção das enfermeiras, provavelmente, não tenha sido fragmentar seus pacientes em partes, não há como negar que, em termos de linguagem, esse sentido está presente, denunciando no mínimo uma certa incompreensão do que elas próprias referem quando mencionam a abordagem do "ser humano como um todo".

$\mathrm{Na}$ linguagem expressa, tudo se passa como se as enfermeiras estivessem referindo-se ao aumento da quantidade das "partes" a serem abordadas no paciente, mas não a seu todo, visto que o conjunto das partes, mesmo que expandidas em amplitude e quantidade, não equivale ao todo. 
E1 “...na faculdade a gente aprende a puncionar uma veia, aprende a fazer um curativo, mas isso realmente você vai aprendendo porque você vai fazendo varias vezes e agora eu começo a perceber que não é só isso, que a gente precisa se aprofundar mais na parte do todo, assim na parte sentimental, da parte social, é isso que eu falo como um todo".

Além disso, elas afirmam que, ao tomarem decisões sobre o cuidar, preocupam-se em saber qual é “a utilidade" de seus atos, o que será proveitoso, acrescentando a idéia do agir pragmático e utilitário.

E1. "...eu acredito muito assim, no ser humano como um todo, então eu levo em conta todas essas características, quando eu vou tomar alguma decisão bem ou mal eu quero pensar bem o que vai ser útil, o que vai ser aproveitado".

No relato das enfermeiras sobre o respeito, um dos conceitos apresentados parece ser o de honrar, cumprir, obedecer e acatar. O depoimento faz menção a regras religiosas ou morais expressas pela noção de hierarquia familiar e social.

E4 "Respeito é uma coisa muito importante, é aquilo que agente aprende em casa, desde o $\mathfrak{B}$-A-BÁ, né! Respeito de pai e mãe, depois respeito com os irmãos, né! Que vai sendo passado para a gente, são valores assim que ... enraizado mesmo de família, né! Aquela coisa de chamar pai e mãe de senhor; de senhora, né uma pessoa de mais idade; e assim é a mesma coisa que a gente tem em relação ao paciente: de estar chamando pelo nome, sem estar colocando apelido, é ... sabe assim, estar respeitando a individualidade do ser humano. Quando você convive com uma pessoa, saber o nome dessa pessoa ,é... 
independente da função que ela tenha, ser sempre tratada com respeito, acho que em termos de convivência... acho que é isso... acho que em cima disso e acho que a formação de casa a gente sempre teve a formação de respeito pelo outro, pela pessoa mesmo em si. embasa o trabalho da gente, a profissão, a vida da gente toda é embasada nesse valor de respeito, de confiança no ser Gumano".

As enfermeiras mencionam um outro conceito de respeito com base na experiência complexa do sofrimento do paciente, fazendo uso, portanto, do conceito de respeito como consideração. Há uma associação de respeito com a compreensão do conhecimento da pessoa que estão cuidando, e o fato de se fazerem conhecer.

Neste caso, parece implícita a necessidade de existir similaridade entre os sujeitos envolvidos, uma vez que só nos é possível compreender as pessoas que compartilham minimamente os modos de ser e estar no mundo, presentes em nosso próprio sistema de representações.

E5 "Respeitar é poder compreender, para mim assim, o quê que essa pessoa está passando, né, conhecer essa pessoa em primeiro Lugar, né! Desde o momento que ele entra aqui, né; eu procuro estar conhecendo a pessoa, tentar o contato, ter uma troca de confecimento, né! Eu me apresento, desde que a pessoa entra a gente já procura se apresentar, deixar a pessoa à vontade num Lugar, né; então a gente sempre coloca em prática este tipo de sentimento para os auxiliares, para toda a Equipe, né! Desde manhã, à tarde, todo mundo. Entrou aqui, é assim, é como se ele se sentisse na casa dele mesmo, a gente 
procura deixar passar isso para a pessoa, sabe? Já fala com a família: olha, pode deixar que a gente vai cuidar bem dele, que ele vai estar em casa aqui, assim; já vê o nome da pessoa, já põe o nome da pessoa lá na parede porque aqui a gente tem o nome né, como na enfermaria tem 3, né, e tem que ter, só de estar colocando o nome afi todo mundo que passa ali já vai chamar ele pelo nome, isso já é uma grande diferença".

E5 "Mas a gente está tentando padronizar esse tipo de orientação, desde que ele chegue justamente ... acho que tudo isso é uma forma de respeito com o paciente. Respeitar o quê que, aquela ansiedade que ele está passando e tudo né, ele vai se sentir bem melhor lógico né, e aí você percebe que muitos né, na hora que vai embora, nossa! Eles ficam super contentes assim com o atendimento, a maioria a gente percebe né?.

Em outra fala, parece haver uma predisposição para o acolhimento do outro na sua diferença, o acolhimento pela estranheza que é o outro, nesse caso, o respeito pela diferença está associado ao amor.

E4 "Acho que é isso, na medida que você respeita, você está... você está amando esse próximo, mesma coisa; pode ser aquela pessoa que você discorda de tudo, de todas atitudes dela, mas você respeita aquela atitude dela, acho que é uma maneira de amar o próximo". 
E2 "... ser humana para tratar as pessoas, respeitando sua religião, respeitando o que elas acham, o que elas pensam e assim trazer um pouco da humanização, individualização".

Os dois últimos casos apontam para compreensão oposta ao conceito de respeito embora, em ambos, estes conceitos não tenham sido mencionados explicitamente.

No primeiro caso, temos a idéia de respeito condicionado ao próprio sujeito, ou seja, as representações da enfermeira seriam os condicionantes do respeito a seu paciente. No segundo caso, o grupo deste estudo trouxe a idéia de respeito incondicionado a si próprio, ou seja, mesmo diante da estranheza e da incompreensão a respeito do outro, há espaço para o respeito; no entanto, essa incondicionalidade é novamente posta em questão à medida que elas associam o respeito ao amor.

O atendimento humanizado, segundo elas, significa você fazer uma boa admissão e prescrição, ter a apresentação entre a enfermeira e paciente, valorizar, respeitar e considerar o paciente como um todo. Elas afirmam obter o respeito e a valorização, colocando-se no lugar de seus pacientes.

E2 "... a humanização, a individualidade você dá quando você faz uma boa admissão, quando você faz uma boa prescrição, quando você conhece ele pelo nome e ele conhece você também pelo nome...". 
E4 “... acho que sou uma pessoa que tive uma formação religiosa, uma formação católica e acho que por conta dessa formação em casa, a gente acredita muito nos valores de humanização mesmo, do valor do ser humano como pessoa, como ser humano...".

E5 "E o atendimento mais humanizado para essa assistência, verificando o todo, a pessoa como um todo, respeitando, se colocando no lugar daquela pessoa... a assistência, avaliando a pessoa como um todo em primeiro lugar".

Esse atendimento humanizado a que elas se referem, aparentemente, não se encontra protocolado pela descrição das ações apresentadas pela instituição nem das atitudes concretas descritas nas falas das enfermeiras. Desta forma, tanto as enfermeiras quanto a instituição parecem basear sua "ação profissional humanizada" em uma noção conceitual vaga que, por sua vez, resulta em ações aleatórias e intuitivas ou apenas discursivas.

E5 “... a mãe a gente deixou também ficar, é quarto de homem, mas até aí, o que a gente foi fazendo, não internava junto, não deixava aquele quarto super Cotado, né, na medida do possível a gente internava em outro quarto porque os outros pacientes ficariam constrangidos com a mãe, né?".

No que diz respeito ao atendimento das necessidades dos pacientes, as enfermeiras definem como: "suprir dúvidas do paciente", "saber o que é importante para ele" e não foi valorizado, "dar apoio". 
Para realizarem, o que chamam de atendimento das necessidades do paciente, elas procuram avaliar o momento, o contexto e nortear suas ações dentro do ético. Relatar ao médico algo que ele não tenha valorizado no paciente, já que elas parecem propor-se a fazer esse intercâmbio, escutar o paciente e, assim, poder solucionar problemas de infra-estrutura da instituição como o conserto de algum aparelho, além de poder ter tempo para conversar, aproveitando o momento para buscar outras informações e completar a história do paciente.

E. 6 "... atender pessoa naquela necessidade que ela mostra naquele momento. Então assim, algumas vezes eu fico um pouco assim... não cerceada assim só que a gente tem varias opções, né a gente tem que estar optando dentro daquilo que é ético, né! Dentro do nosso agir, mas é como eu te disse, eu não gosto das coisas muito pré-estabelecidas, muito já determinadas. Eu acho que a gente tem que avaliar o momento, tem que avaliar aquele contexto que está acontecendo, para poder nortear bem a sua ação. Então eu procuro ao máximo estar assistindo a pessoa desta maneira".

$\mathcal{E} 1$ "É porque de repente a gente faz um intercambio entre o medico e o paciente, quando eu falo em suprir também é de duvidas que ele tem ou alguma coisa que ele sente falta, ele acha que e importante e não foi valorizado, eu acho nesse sentido, suprir as necessidades mesmo né”.

E3 “... dedicar esse tempo a escutar o paciente, a observar, a parar realmente, falar com ele para saber o que é importante para ele, E depois, dai de acordo com a minha posição aqui dentro, de com o poder que eu tenho para algumas 
coisas, tentar consertar uma coisa ou outra no sentido de atender às necessidades desse paciente".

E1 "Eu acho assim que dar apoio é você poder ter tempo para conversar, de ver antecedentes, pegar assim a historia do paciente, ir conversando, falando até mesmo de valor, o que é importante para ele, o que não é, o que realmente preza, o que ele sente falta que a gente mesmo como enfermeiro, não supre tudo mas tentar suprir algumas".

Nos relatos das enfermeiras, foi possível apreender que a empatia é outro valor importante, considerada por elas como "se colocar no lugar da outra pessoa". O modo como descrevem suas atitudes para atingir este fim, é valorizando o que seria importante para elas se estivessem internadas e atendendo o paciente, proporcionando-lhe, com base nesta referência, conforto e segurança. Elas acreditam que isto é o que paciente precisa, quando está hospitalizado.

E3 “...uma coisa que embasa muito é a questão da empatia, de você se colocar no lugar do outro ... eu se tivesse no lugar dessa pessoa eu gostaria de me sentir segura, então; valorizar a segurança que a gente pode proporcionar para o paciente, os cuidados é... deixar essa pessoa confortável, à vontade ... e ao mesmo tempo se ela se sentir segura, ela fica mais à vontade. eu coloco aquilo que eu tenho em comum, que eu valorizaria enquanto paciente e tento fazer isso por ele né? ... só que algumas coisas fogem, a gente não consegue ir de encontro a todas as necessidades, aquilo que a gente... as expectativas. valor está mais, assim, naquilo que o outro deseja de mim, daquilo que ele 
espera que eu faça por ele.Então a gente tem que ir de encontro, buscando o quê? A satisfação deles“.

E3.: "É, eu acho assim, que é o começo de tudo assim...porque, olha; eu me coloco no lugar de alguém, né! Aí, eu imagino : se eu tivesse com câncer e fosse fazer uma cirurgia, né! Eu queria o quê? Eu ia querer saber o que estava... que acontece, como vai ficar. Me coloquei no lugar... Primeiro me coloquei do lugar do paciente. Me colocando no lugar do paciente, eu vou querer saber, querer ter segurança, saber que tem alguém que realmente conhece o meu problema, saber o que faz por mim. Alguém que entende, que se dispõe a me ouvir, e se preocupa com aquilo que eu estou passando é... querer...querer conforto sentimental e... Aí vai, primeiro a empatia, depois da empatia, você quer alguém honesto, alguém com quem eu me sinto seguro, né! $\mathcal{E}$ aí, eu começo a proporcionar segurança, proporcionar apoio, honestidade, sinceridade. A honestidade, sinceridade... também não só com relação ao paciente, mas com relação aos colegas também, né!"

E5 “... então eu acho que só a gente se colocando no lugar da pessoa realmente para poder sentir o que ela está sentindo também, né?"

Elas também relatam que atender o paciente é fazer por ele o que gostariam que fizessem por elas, e a ação correspondente a isso é ouvir as solicitações do paciente.

E6 "É estar fazendo para alguém da maneira como eu queria estar recebendo. Então, eu acredito bastante neste atendimento individual, no fato de você estar ouvindo o que o paciente está te pedindo, então assim eu não gosto de 
coisas muito... muito quadradas, muito preestabelecidas, então eu sempre tento trabalhar com esse individualismo de cada pessoa".

Encontramos nesses depoimentos mais uma vez, o uso da mesma palavra, neste caso, "empatia", comportando idéias opostas. Na primeira, é possível inferir que há o conceito subjacente, segundo o qual "eu sou referência para as outras coisas". Parece estar claro e logicamente sustentada a idéia de que "o que é bom para mim, é também bom para o outro".

No segundo núcleo de idéia sobre empatia, surge pela primeira vez a referência à voz do paciente e, neste caso, também está subjacente a idéia de que é possível que "eu não saiba do que ele precisa, uma vez que cada pessoa possui necessidades que podem ser absolutamente estranhas a mim". Essa idéia justifica o atendimento individualizado mencionado na fala de uma das enfermeiras.

Analisando agora conjuntamente os valores que fundamentam o cuidar das enfermeiras nesse estudo, é importante esclarecer cada um desses pontos.

No que diz respeito à valorização do ser humano, é interessante antes entendermos o que seja essa valorização nos conceitos teóricos gerais e, posteriormente, neste grupo em específico.

Quando experimentamos a valorização, é porque reconhecemos algo como valioso, julgando e apreciando, emitindo um juízo de valor. 
Segundo Hessen ${ }^{(6)}$,

não é possível a vida sem proferir constantemente juízos de valor. É da essência do ser humano conhecer e querer, tanto como valorar. Todo o querer, com efeito pressupõe um valorar. Nada podemos querer senão aquilo que de qualquer maneira nos pareça valioso e como tal digno de ser desejado

Os nossos juízos de valor podem ser positivos e negativos, nem tudo pode representar valores positivos, pode acontecer que correspondam até a valores negativos ou desvalores. ${ }^{(6)}$

“Valor pode dizer-se é a qualidade de uma coisa, que só pode pertencer-Ihe em função de um sujeito dotado com uma certa consciência capaz de registrar". (6)

De qualquer forma, essas definições dizem respeito a conceder valor a coisas, objetos, e quando se usa o termo valor a algo que não é objeto, se está atribuindo valor a um dom ou a uma característica, portanto, quando se fala em valorização do ser humano, estamos qualificando no ser humano um determinado atributo e não a ele propriamente dito. Ao ser humano, não é possível emitir um juízo de valor, pois este é intrínseco a si próprio e não depende do julgo de terceiros.

No caso do grupo abordado neste trabalho, podemos observar o que as enfermeiras denominam como valorização do ser 
humano, corresponde a uma intenção de ajuda que, muitas vezes, está baseada em protocolos como a Sistematização da Assistência de Enfermagem (SAE).

Assim, a valorização do ser humano parece estar mais dirigida a si própria, às suas ações e atitudes relacionadas à ajuda do que ao olhar e ao julgamento sobre o outro, além de aparentemente, existir uma certa relatividade do valor do outro ao empenho que as enfermeiras despendem a ele, ou seja, o outro tem valor na medida que dedicam mais tempo a ele.

Nas falas de algumas dessas enfermeiras, merece destaque a correspondência quase absoluta que parece haver entre um tema, cuja natureza é essencialmente ética, reflexiva e abstrata com outro que é concreta, pragmática e operacional como são os protocolos assistenciais e a própria Sistematização da Assistência de Enfermagem, dando espaço à suposição de que existe uma falta de intimidade com questões que demandem reflexões e posições pessoais.

É interessante perceber também que na relação estabelecida entre a enfermeira e paciente, a intenção de ajuda parece estar associada ao sentimento de compaixão.

Vale evidenciar aqui a distinção entre compaixão e solidariedade, embora as enfermeiras deste estudo não se detenham em dar profundos significados a esses termos, talvez, a distinção apresentada pela autora em questão seja pertinente, não pelos termos 
propriamente ditos, mas, pela reflexão que nos permite em torno do estilo da relação que se estabelece entre os sujeitos envolvidos em um e outro caso, definindo possibilidades diferentes de autonomia, liberdade, eqüidade e respeito em cada um deles, mostrando qual se aproxima mais do estilo da relação descrita pelas enfermeiras deste estudo com seus pacientes.

Para Camponi ${ }^{(31)}$, a solidariedade pode ser definida como

um vínculo que se estabelece entre pessoas que se podem reconhecer, pelo menos, virtualmente, como iguais, como sujeitos com capacidade de estabelecer um diálogo onde sejam avaliados as razões e os limites do auxílio prestado.

A autora enfatiza ainda que a solidariedade encontra seu fundamento na simetria dos interesses, numa 'desapaixonada comunidade de interesses' com os infortunados, na medida em que todos compartilham uma única preocupação por universalizar a "dignidade humana" (31)

Por sua vez, a compaixão revela-se como uma tecnologia de poder que aparece caracterizada de "humanismo". Ela

instaura uma modalidade peculiar de poder estruturada a partir do servir-obedecer. Pois a pessoa compassiva não mede se as conseqüências deste socorro imediato são ou não desejados, além de caracterizar quem a recebe como 
alguém que só pode superar suas limitações pelo socorro oferecido, e quem a dá se engrandece ao realizar a ação (31).

Apoiadas nas conceituações aqui apresentadas, vale colocarmos em questão, qual das duas descrições parece aproximar - se mais do estilo de relação que as enfermeiras do estudo estabelecem com seus pacientes, e qual seria a compatibilidade que esse estilo possibilita com os demais valores que elas relatam.

No que se refere à idéia ser humano como um todo, e considerando a ampla abrangência e complexidade da integralidade do homem, temos visto que, ao longo da história das ciências relativas ao homem, ele tem sido até nossos dias compreendido de modo fragmentado. O fato não se refere unicamente às ciências que estudam o próprio homem, mas, a todas as outras derivadas do pensamento humano.

Analisando o modo como se dá a construção do conhecimento e como opera o pensamento humano, teóricos vêm afirmando, ao longo dos séculos, que esta operação baseia-se fundamentalmente na lógica de causalidade ou, na melhor das hipóteses, na lógica da probabilidade e correlações entre fatos. Não há indícios de que sejamos capazes de compreender intuitivamente situações bastante complexas, como é o caso do homem agindo, reagindo e interagindo simultaneamente em sua integralidade interna e externa. 
Além disso, a complexidade do ser humano é tal que falar em ser humano como um todo, é algo que nos é inacessível sobretudo se considerarmos seu dinamismo, sua plasticidade e a indefinição do contorno que chamamos de todo.

Nossa existência está em contínua formação e falar em todo, seria referir-se a algo já acabado, logo basear nosso cuidar no princípio de ser humano como um todo, parece ser algo inconsistente, inatingível ou ingênuo.

Aquilo que nos resta para qualificarmos o cuidar com base nas ciências que conhecemos, é ampliar o olhar sobre esse paciente ampliando também o domínio do conhecimento científico nas diferentes dimensões humanas e nas ciências que as abordam, mas, para tanto seria preciso que, anteriormente, se adquira mais conhecimentos a respeito das ciências humanas, pois, caso contrário não se saberá nem o significado daquilo que o paciente já apresenta.

No entanto, é necessário enfatizar que as ciências são apenas o ponto de partida para o entendimento do ser humano, apenas a condição mínima de possibilidade de sairmos do estado de ausência de conhecimento absoluto, relativo às questões humanas, porém não são nem de longe a via de esgotamento dessa compreensão. Em outras palavras, essas ciências são necessárias, mas, não suficientes.

Assim, a ciência não pode trazer senão vantagens, contanto que se reconheça seus limites: limites de 
possibilidades e limites de resultados. Nunca as ciências exatas - matemática e física poderão conhecer com seus métodos de medição e experimentação o homem todo, exatamente porque o homem é algo mais que pura natureza física. ${ }^{(32)}$

A possibilidade de ampliação do conhecimento do ser humano, para além das ciências, poderá e deverá também ser buscada na qual o próprio ser humano se expressa e revela-se como, por exemplo, nos dilemas cotidianos, nas artes de uma forma geral, entre outras expressões. Isso porque é por meio desses dilemas que refletimos sobre questões de conduta, de escolhas e nas artes porque tem a particularidade de refletir aquilo que a alma não pode dizer por meio de palavras.

Outra idéia significativa relatada pelas enfermeiras referese à utilidade de suas ações, ou seja, ao desejo de ser útil aos pacientes, porém, quando se fala de utilidade é necessário fazer uma revisão teórica sobre essa questão, que pode ter diferentes sentidos: útil significa "o meio ou instrumento para um fim qualquer", nesse caso tem um caráter de coisa.

Desde Hobbes (século XVII), foi chamado de útil o que favorece a conservação do homem ou, em geral, satisfaz às suas necessidades ou a seus interesses $O$ utilitarismo como doutrina historicamente determinada é uma tendência do pensamento ético, 
político e econômico inglês, dos séculos XVIII e XIX, é uma tentativa de transformar a ética numa ciência positiva da conduta humana. ${ }^{(33)}$

Neste caso, a utilidade aparece como um modo de conceber um valor moral, inserido num contexto de relações sociais que visa a uma discussão em torno do estado de direito das pessoas numa sociedade. Mas o significado de útil também pode estar ligado à tecnologia "o técnico mais do que o cientista vê tudo sob o aspecto da utilidade, num certo sentido criar utilidades é a própria função da técnica". ${ }^{(32)}$

Neste caso, esse "utilitarismo" mencionado por uma das enfermeiras deste estudo parece desvendar um valor moral baseado no estado de direito de seu paciente e na tecnologia, da qual ela deve dispor para atendê-lo. Os valores morais parecem ser legítimos e necessários às relações sociais civilizadas e qualificadas, mas não são suficientes para atender a outras demandas éticas que as próprias enfermeiras citam como suas, isto é, não englobam a possibilidade da relação humana no que se refere ao encontro face a face, ou seja, na relação entre subjetividades é o que as enfermeiras deste estudo pretendem que ocorra no encontro entre elas e o paciente.

Para que ocorra a relação face a face, é necessária a aproximação entre duas pessoas, um encontro onde ambos estão presentes e no qual existe reciprocidade. Nessa relação, instaura-se a alteridade, na relação em que não há reciprocidade, o outro não é encontrado como tal. ${ }^{(34 ; 35)}$ 
"O homem é um ser de relação" (35), para que haja essa aproximação há um desvelamento do outro e de si, entre paciente e enfermeira. Estar aberta para a outra pessoa é colocar-se em um mesmo plano, numa relação que implica confiança e coragem, pois, ao mesmo tempo, requer uma atitude amorosa (abrir-se para o outro), ela também implica um vulnerabilizar-se diante do outro. A relação face a face é, pois um expor-se ao outro a despeito das conseqüências dessa exposição e olhar o outro apesar da revelação que se fará.

Ao apropriar-se das informações sobre o paciente, a enfermeira investe seu fazer em desvelar e desvendar o outro, no entanto, em suas ações cotidianas, a reciprocidade desse desvelamento, como é sugerido nos seus relatos, está prevista. Então, é possível questionar o quanto de fato elas investem nessa relação face a face? Será que seria desejável uma relação face a face com o paciente? Se na maioria das nossas relações há limites e condições de desvelamento porque também não deve haver na relação com o paciente? Na medida que referem seu desvelamento para com o paciente, elas o descrevem como sendo o ato de se apresentarem, ou seja, apenas dizer seu nome e seu cargo no interior do grupo que atenderá.

Parece haver um certo "filtro moral", coibindo o reconhecimento de que o encontro com o paciente caracteriza-se muito mais como um encontro entre atores sociais do que propriamente entre sujeitos. 
Assim, nessas situações, o que parece ocorrer, é uma intenção de incondicionalidade no atendimento ao paciente, mas parece haver também um certo descompasso entre intenção e comportamento descrito por elas.

No que se refere a um outro elemento do cuidado, é interessante perceber que, na relação com o paciente, as enfermeiras relatam a importância do respeito por ele, associado a uma ação cognitiva de compreender e conhecer a pessoa, ou seja, a enfermeira indica que o respeito de algum modo precisa ancorar-se num esquema de sentidos ou de representações preexistentes em seu sistema de referências, em outras palavras é provável que haja a indicação de que a enfermeira é sua referência para seu pensar e respeitar o outro.

Dessa forma, parece que há um condicionamento do respeito às próprias referências, ou seja, é necessário compreender para respeitar. A compreensão do outro estaria em apreender a lógica de seu pensamento, aquilo que justificaria seu ato, seria buscar a compatibilidade entre as lógicas de ambos. Posto dessa forma, o respeito ao outro se torna impossível, visto que compreender o outro é praticamente inatingível pelo simples fato do outro ser algo que não sou e, portanto, incompreensível para mim.

Com relação a essa idéia, para conhecer de fato o Outro enquanto subjetividade eu teria de ser, eu mesmo, "sujeito da consciência dele", isto é, transformar-me na consciência alheia. Isso eliminaria já qualquer alteridade 
... eu e o Outro seríamos o "mesmo", o que é absurdo. Portanto, o simples conhecimento do Outro não me dá condições de apreendê-lo enquanto sujeito...(36)

O respeito é definido como o reconhecimento da dignidade própria ou alheia e o comportamento inspirado nesse reconhecimento e a dignidade por sua vez significa que todo homem, aliás todo ser racional, como fim em si mesmo, possui um valor não relativo (como é, por exemplo, um preço), mas, intrínseco, isto é a dignidade. ${ }^{(33)}$

Trata-se de uma relação efetivamente dialética: ao voltarme para mim mesmo, encontro o outro e, para voltar-me para ele, é necessário que eu me volte sobre mim mesmo, conforme a relação intersubjetiva não há possibilidades de conhecimento sem que sejam afetados os dois pólos. Estamos falando, portanto, da exigência essencial de um respeito mútuo na relação entre os indivíduos ${ }^{(37)}$

ou seja, a relação de respeito não é um que considera o outro, mas, ambos se consideram. Essa relação pressupõe reconhecer o espaço da outra pessoa.

Na relação da enfermeira com o paciente, de um modo geral, esta condição parece não estar favorecida e uma possível justificativa para isso, citada em alguns estudos como o de Menzies(38), 
Borsoi $^{(39)}$ como meio inconsciente delas, muitas vezes, lidarem com a ansiedade decorrente da natureza de seu trabalho, seria considerar a própria defesa da enfermeira. Ao identificar o paciente como alguém diferente de si, muitas vezes, ela busca proteger-se de uma angústia, pois colocar-se no mesmo plano do paciente significaria admitir que ela também pode adoecer, sofrer e morrer.

Estes sentimentos mostram um grande sofrimento, e para amenizá-los a enfermeira recorre a mecanismos de defesa e tanto quanto possível, isso é feito pela eliminação de situações, acontecimentos e relacionamentos que evocam ou causam ansiedade. No trabalho de Menzies(38), observamos que o fundamento, a base da situação de ansiedade para a enfermeira reside em sua relação com o paciente e quanto mais intimo for esse relacionamento, mais ela estará propicia a ansiedade.

Já no trabalho de Borsoi $^{(39)}$ observamos que a relação da enfermeira com o paciente torna-se mais distante, pois, de acordo com a função imposta pela instituição, ela fica encarregada do planejamento e supervisão do conjunto do trabalho, distanciando-a do paciente. Além disso, a enfermeira passa a lidar com sentimentos contraditórios, marcados pelo afeto, pela ansiedade e por um sofrimento psíquico.

É preciso ter a clareza que, quando se está nesse universo de defesa, não há como reconhecer valores, não é possível ter respeito pelo outro, no sentido mais restrito da expressão porque também não há outro. Neste caso, chamar o paciente pelo nome, apresentar-se falando 
apenas seu nome ou passar informações aos familiares pelo telefone, talvez, seja o único respeito possível diante de um outro não identificado.

O respeito pertence à própria pessoa, não é dado, mas pode ser afetado. Quando, muitas vezes, durante a assistência ao usarmos as expressões "tem que" "o senhor tem que tomar este remédio", podemos estar violentando o respeito, ou seja interferindo no direito da outra pessoa decidir pela sua própria vida.

Neste estudo, as enfermeiras, entre outras coisas, conceituaram o respeito ao paciente como uma forma de amor ao próximo. Vale lembrar que o encontro entre enfermeira e paciente é circunstancial, compulsório. Esse dado opõe-se ao conceito de amor que é, absolutamente, eletivo e seletivo, o que sugere que no encontro enfermeira-paciente não existe e não deve existir a obrigatoriedade do amor, mas, o respeito.

Um outro conceito de respeito considerado por elas, é a hierarquia, pelo papel social, neste caso, longe de haver uma aproximação e um reconhecimento do outro. O foco é o cumprimento de regras sociais estabelecidas, pois, quando se fala de hierarquia o foco não é o sujeito e, sim, seu papel social e, por isso, é pouco provável o encontro ou o desvelamento dos sujeitos envolvidos, uma vez que estão ocultos por seus papéis sociais. 
A predisposição para a abertura e o respeito ao outro também nos faz rever o sentido da humanização do cuidado que, é definido como:

...um processo de construção gradual realizado pelo compartilhamento de conhecimentos e sentimentos, nessas ações de humanização, procura-se resgatar o respeito à vida humana, da enfermeira e do paciente. ${ }^{(40)}$

Diferente desse conceito e que parece ser uma situação comum nos hospitais, é que estes são lugares onde as pessoas sentemse diminuídas, despersonalizadas e isoladas e na preocupação com a busca da cura e da perfeição técnica, o doente pode ser transformado em mero receptáculo de cuidados. Seu conforto físico e mental fica subordinado a restrições impostas pela instituição e pelas recomendações terapêuticas.

Ao conceituar humanização hospitalar entende-se que o hospital "humanizado" é aquele em que sua estrutura física, tecnológica, humana e administrativa valoriza e respeita a pessoa(41).

No entanto, podemos perceber pelo relato de algumas enfermeiras deste estudo que há uma preocupação relacionada prioritariamente ao ambiente e à estrutura física do setor em detrimento da pessoa. Os valores que predominam, via de regra, são conhecimento científico e habilidade técnica. 
Esta ênfase pode também determinar a necessidade de profissionais cada vez mais especializados. Isso pode ter um lado positivo, pois hoje se tem muito mais conhecimento científico do que há anos, mas, por outro lado, isso leva a fragmentação do cuidado, e há uma tendência maior a se tratar da patologia, que é de sua competência, e com isso é tirado do ser humano aquilo que ele tem de mais precioso, que é sua dignidade. ${ }^{(42)}$

A humanização dos cuidados de enfermagem em uma unidade relaciona-se, sobretudo, às atitudes de cada uma das pessoas que prestam os cuidados, mais do que qualquer alteração relacionada à estrutura ou à tecnologia. Embora a tecnologia seja necessária, não justifica sua hipervalorização nem sua utilização como substituta do contato e da presença do profissional com o paciente.

A humanização hospitalar como proposta adequada para qualificar humanamente o atendimento ao Outro, deve incrementar o processo de crescimento, de valorização e investimento na formação humana dos sujeitos que integram as instituições. $^{(43)}$

Assim, quanto mais articularmos o conhecimento teórico e técnico da ciência aos aspectos afetivos, sociais, culturais e éticos da relação profissional-paciente, mais estará no caminho para uma relação mais humana e eficaz. ${ }^{(40)}$ 
Para Arendt $^{(44)}$ por muito intensamente que as coisas do mundo nos afetem, por muito profundamente que possam emocionar-nos, não se fazem humanas para nós a não ser que haja o momento em que possamos debatê-las com nossos semelhantes. Tudo que não pode chegar a ser objeto de diálogo, pode muito bem ser sublime, horrível, misterioso, pode até encontrar a voz humana através da qual ressoe no mundo, mas não é, verdadeiramente, humana.

Quando pensamos em relações humanas, particularmente, nos casos da relação paciente-enfermeira, parece que elas consideraram em seu cotidiano o conhecimento científico só da esfera biológica, tanto que não fazem referência às ciências humanas e sociais, mesmo quando relatam que atendem as necessidades dos pacientes. É importante ressaltar que, para que se tenha uma qualidade no atendimento, é preciso a integração crítica desses conhecimentos.

O atendimento das necessidades do paciente, outro significado apreendido nos discursos das enfermeiras, tem várias definições, como: algo imprescindível, inevitável, ou ainda, exigências mínimas para satisfazer condições materiais e morais de vida ${ }^{(45)}$, mas de qualquer maneira quando se fala em atender as necessidades é preciso, antes de tudo, identificar quais são essas necessidades a que se referem, pois à medida que não são identificadas, é impossível intervir e atender o paciente naquilo que Ihe está afetado. 
Assim, é nesta ilusão do suposto engrandecimento 'moral' de si, que impede pensarmos que talvez, nosso gesto de compaixão não seja desejado; que possa ter conseqüências negativas para o 'beneficiário' ou que, simplesmente, possa gerar e promover estados de dependência e submissão. Algo assim acontece quando sufocamos o doente com cuidados que ele próprio poderia assumir, quando pelo bem de algumas pessoas 'inconvenientes' as preferimos excluir, ou quando acreditamos conhecer as necessidades dos outros, antes mesmo de solicitadas. ${ }^{(31)}$

As necessidades são identificadas, conforme reconhecemos a outra pessoa e, também, a nós próprios, porém o que parece ocorrer por meio dos relatos é que as enfermeiras deste estudo distinguem as necessidades na outra pessoa a partir de suas próprias referências, ou ainda, quando não reconhecem quais são as necessidades afetadas, é possível que a intervenção baseie-se na projeção de suas próprias necessidades e na tentativa de avançar e superar o agir intuitivo, do senso comum.

Aparentemente, é com base nessa projeção que se constitui a empatia para essas enfermeiras, pois elas conceituam empatia como se colocar no lugar do paciente, mas tendo a si próprias como referência, é provável que dispensem a voz do paciente. Atender a 
outra pessoa tendo a si própria como referência, é uma forma de atender a si própria, a seu conforto e segurança.

Há diversas definições de empatia, é a “intuição daquilo que se passa no outro, sem, contudo esquecer-se de si mesmo, pois nesse caso, tratar-se-ia de identificação" (46). Para C. Rogers apud Daron $^{(46)}$, “a empatia consiste em captar, com maior exatidão possível, as referências internas e os componentes emocionais de uma outra pessoa e compreendê-los como se fosse essa outra pessoa".

A empatia parece abordar um componente cognitivo e um afetivo. O primeiro, conhecido como adoção de perspectiva, caracterizase por uma capacidade de compreender acuradamente a perspectiva e os sentimentos dos outros, quer seja por meio de processos inferenciais, de representações estocadas na memória ou colocando-se no lugar de outra pessoa. O segundo, menos elaborado e sofisticado, é conhecido como comportamento prossocial e caracteriza-se por sentimentos de compaixão e simpatia pela outra pessoa, além da preocupação com o bem-estar desta. O contágio emocional e o mal-estar pessoal não são considerados manifestações empáticas. Estas reações correspondem a manifestações pré-empáticas. ${ }^{(47)}$

A adoção de perspectiva e o comportamento prossocial não são suficientes para a manifestação do comportamento empático. Algumas pessoas podem ser capazes de compreender acuradamente o estado interno de alguém e sentir verdadeiro interesse em ajudar, porém não manifestam essa compreensão ou fazem-na de forma não empática. 
O comportamento empático caracteriza-se pela habilidade de compreender precisamente os sentimentos e a perspectiva da outra pessoa, e transmitir o atendimento, de tal modo que ela se sinta compreendida e acolhida e isto a ajuda a obter um maior entendimento a respeito de seus sentimentos. ${ }^{(47)}$

Para que ocorra a empatia, é preciso estar atento de modo bastante especial. Prestar atenção em alguém, neste sentido, significa estar com esse alguém física e psicologicamente. ${ }^{(48)}$

Aparentemente, o que ocorre na relação entre paciente e enfermeira, embora pareça existir a intenção de ajuda, não é uma relação empática, pois, novamente, as enfermeiras colocam-se como referência para o atendimento ao paciente.

Quando relatam "se colocar no lugar do outro", essas enfermeiras demonstram mais uma vez sua dificuldade de conceber a alteridade, de colocar-se em suspensão de distanciar-se de si própria e de suas perspectivas para possibilitar o desvelamento do outro. Parecem denunciar também um certo descuido ou desatenção pela fala de seus pacientes, à medida que sua expressão verbal não é imprescindível para que saibam do que precisam. Assim, essa informação para elas, pode ser obtida a partir delas próprias e não necessariamente de seus pacientes. 


\section{CONSI DERAÇÕES FI NAIS}

Este estudo permitiu uma compreensão a respeito dos valores que norteiam o agir dessas enfermeiras.

Parece ter havido por parte dessas enfermeiras uma intenção de serem éticas e desejarem fazer o melhor para o paciente. Essa intenção pode ser observada, inclusive, pelas expressões que utilizaram, como: "o conhecimento é o valor mais importante para agir", "considerar o paciente como um todo", "valorizar o ser humano", entre outras.

Para atuarem de modo eticamente correto, as enfermeiras usaram conceitos que, na maioria das vezes, pareceu ser os do senso comum. Por exemplo, quando expressaram termos como dignidade, respeito, empatia, parece não ter havido uma conceituação clara a respeito desses valores, o que pode mostrar uma reflexão superficial.

Os conceitos desses valores utilizados ingenuamente podem dificultar a construção do sujeito ético, que se dá por meio de escolhas e da tomada de decisão, depois de ponderações do próprio agir.

No seu cotidiano, o ser humano vê-se envolvido pela necessidade de fazer escolhas, algumas simples outras mais complexas, mas, cabe a ele refletir e decidir entre as opções que lhes são citadas. As 
escolhas são um ato intransferível, pois mesmo o fato de não escolher é uma opção de transferir ao outro a responsabilidade pelo ato, e como refere Sartre, "o homem está condenado a ser livre", condenado não porque possa realizar todos os seus desejos, mas porque é sempre obrigado a optar". ${ }^{(36)}$

Dessa forma, o ser humano sendo livre e responsável é capaz de fazer opções éticas, expressando, assim, a sua humanidade. As escolhas e decisões que ele faz estão diretamente ligadas ao projeto de vida de cada indivíduo e, com base nesse projeto, cada um constrói a sua própria existência e, é responsável por ela. Assim, ao “continuarmos a existir, prosseguimos na escolha de nossos fins, pois a liberdade é a essência de nossa existência"(49).

Além disso, "a cada instante temos que optar por um valor, uma regra de conduta. Nada nos diz que decisões tomar, nada justifica a adoção de um valor em detrimento de outro, exceto a consciência". Por outro lado, os valores estão, com freqüência, vinculados à noção de preferência ou de seleção, e nos compromete na medida que nos obriga a nos posicionarmos diante dessas escolhas. ${ }^{(36)}$

Assim, é possível considerar a liberdade um valor que pode sustentar outros valores, já que parece ser possível fazer opções éticas no momento em que se tem liberdade.

"Os valores dependem da nossa liberdade, do livre impulso que em nós se manifesta para agirmos em certa direção 
seja ela qual for. O valor é um propósito que se justifica em si mesmo, e portanto nenhum valor é gratuito, posto que depende do compromisso que cada homem assume com suas decisões. ${ }^{(51)}$.

Para Kant, a liberdade é uma condição 'sine qua non' da Ética, pois esta “movida pela razão, não se limita ao Ser enquanto realidade que atualmente vivenciamos, mas se reporta à esfera de dever ser, enquanto o homem, livre e dotado de razão, não se limitaria a seguir um código de ética externo, mas buscaria pela sua razão, máximas que pudesse universalizar e as cumpriria pelo respeito e dever às mesmas.

Relacionando essas questões com o agir das enfermeiras, construído, aparentemente, a partir de uma ética bem intencionada, parece haver um equivoco, pois pela maneira como tomam suas decisões, elas negligenciam a autonomia e liberdade tanto do paciente, como a equipe quando, por exemplo, decidem por eles segundo seus critérios e valores.

Ao negligenciar essa autonomia e liberdade, as enfermeiras parecem estar mais voltadas ao comando, ao controle do paciente e da equipe, mas pode-se observar que não é possível controlar ou cercear totalmente a liberdade de alguém, como cita Sartre "a liberdade alheia é um campo fora de ação", pois eles encontram meios de manifestar algumas decisões suas. 
É possível que as enfermeiras, com suas atitudes de controle, causem um adiamento do projeto de vida do paciente e ou equipe, assim, ao invés de contribuir com o crescimento, ela estará sendo um obstáculo ao projeto de existência deles, inclusive quando, por exemplo, diz que "valoriza aquela pessoa como ser humano" ou que os funcionários são como a "extensão do seu braço". Nestes casos, parece que elas se colocaram numa condição diferente, ou seja, de superioridade em relação aos outros sujeitos.

Assim, a partir do exposto, este trabalho pode fornecer subsídios que possibilitem contribuir com as reflexões sobre o papel do docente no agir da enfermeira.

Ao tomarmos como referência a formação das enfermeiras, podemos pressupor que, ainda hoje, nos Cursos de Graduação em Enfermagem, de forma geral, é dada uma ênfase maior no modelo biomédico, além de se priorizar os procedimentos terapêuticos e tecnológicos. Assim, acreditamos que no decorrer do curso deveriam ser ministrados conteúdos específicos e utilizar técnicas no sentido de instrumentalizar o aluno, futuro profissional, a identificar e lidar com as situações do seu cotidiano, além de qualificar sua assistência, pois parece que o que é administrado hoje ainda é insuficiente, ou pouco articulado com a ética e com a reflexão dos valores.

Direcionar reflexões aos alunos fazendo aflorar questionamentos a respeito das relações estabelecidas e do agir, pode contribuir na construção da compreensão da natureza humana. 
No que diz respeito às enfermeiras, para que a compreensão da natureza humana ocorra, e elas possam tornar o seu agir melhor, ou mais qualificado, a reflexão e discussão a respeito de seu agir ético são importantes, pois à medida que se faz um exercício da sua liberdade, é feito um exercício ético. Por meio de suas escolhas, é possível constituir-se como um sujeito ético.

Agindo dessa forma, as enfermeiras trazem para si a responsabilidade das decisões que adotaram. Estas reflexões e discussões devem ocorrer mediante as várias ciências que tratam do assunto, como a psicologia, a filosofia que pode, de alguma forma, contribuir para uma melhor relação melhor com a equipe, com o paciente e com a própria instituição.

Desse modo, é possível que, ao se adotar uma abordagem mais reflexiva para a compreensão do agir da enfermeira, considerando as possibilidades de escolha e os significados atribuídos às suas vivências, esses profissionais poderão ter a oportunidade de atuar de maneira mais qualificada em relação ao paciente e à equipe. 


\section{REFERÊNCI AS BI BLI OGRÁFI CAS}

1. Moreira TA. Compreendendo a vivência do paciente cuidado por aluno de enfermagem. [dissertação] São Paulo (SP): Escola de Enfermagem da USP; 1998.

2. Serino SAL. Diagnóstico compreensivo simbólico: uma psicossomática para a prática clínica. São Paulo: Escuta; 2001.

3. Vergnieres S. Ética e política em Aristóteles: physis, ethos, nomos. Trad. de Constança Marcondes César. São Paulo: Paulus; 1998. ( Ensaios filosóficos).

4. Hare RM. A linguagem da moral. Trad. de Eduardo Pereira Ferreira. São Paulo: Martins Fontes; 1996.

5. Werneck VR. Educação e sensibilidade: um estudo sobre a teoria dos valores. Rio de J aneiro: Forense Universitária; 1967.

6. Hessen J. Filosofia dos valores. Trad. de L. Cabral de Moncada. São Paulo: Saraiva; 1946.

7. Silva FL. Breve panorama histórico da ética. Bioética [periódico online] 1993; 1(1). Disponível em:

http://www.cfm.org.br/revista/biolv1/brevepano.html nov.2001).

8. Frondizi R. ¿Qué son los valores? Introducción a la axiología. 6ạ ed. México: Fondo de Cultura Económica; 1986.

9. Alves VH. O ato da amamentação: uma questão de valor ou um valor em questão. [tese] Rio de Janeiro (RJ): Escola de Enfermagem Anna Nery; 2003. 
10. Gonçalves A. A ética material dos valores de Max Scheler. In: Virtual Avenue [online]. Burlington; 2002. Disponível em: $<$ http://lareira. virtualave. net/arlindoaeticamaterial.html> (9 abr. 2002).

11. Critelli DM. Analítica do sentido: uma aproximação e interpretação do real de orientação fenomenológica. São Paulo: EDUC/ Brasiliense; 1996.

12. Grandesso MA. Sobre a reconstrução do significado: uma análise epistemológica e hermenêutica da prática clínica. São Paulo: Casa do Psicólogo; 2000.

13. Macedo RMS. Prefácio. In: Grandesso MA. Sobre a reconstrução do significado: uma análise epistemológica e hermenêutica da prática clínica. São Paulo: Casa do Psicólogo; 2000.

14. Braida, CR. Apresentação. In: Schleiermacher FDE. Hermenêutica: arte e técnica da interpretação. Trad. e apresentação de Celso Reni Braida. 3ạ ed. Petrópolis: Vozes; 2002.

15. Schleiermacher FDE. Hermenêutica: arte e técnica da interpretação. Trad. e apresentação de Celso Reni Braida. 3ạa ed. Petrópolis: Vozes; 2002.

16. Gadamer HG. Verdade e método II: complemento e índice. Trad. de Enio Paulo Giachini. Petrópolis: Vozes; 2002.

17. Conselho Nacional de Saúde. Resolução n. 196, de 10 de outubro de 1996. Diretrizes e normas regulamentadoras de pesquisa em seres humanos. Bioética 1996; 4(2 Supl): 15-25.

18. Fontes C. Estatuto do conhecimento cientifico. In: Filorbis. Navegando na Filosofia [online]. Lisboa; 2001. Disponível em: 


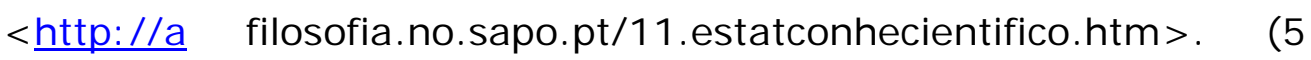
nov. 2001).

19. Cella M, Pellella G. Popper e Kuhn: considerações sobre a ciencia. [online]. Disponivel em: $<$ http:// sites.uol.com.br/cynthia_m_lima/pokuhn.htm>. (6 fev. 2002).

20. Chalmers AF. O que é ciência, afinal? São Paulo: Brasiliense; 1993.

21. Geovanini T, Moreira A, Schoeller SD, Machado WCA. Historia da enfermagem: versões e interpretações. $2^{\underline{a}}$ ed. Rio de Janeiro: Revinter; 2002.

22. Polit DF, Hungler BP. Fundamentos de pesquisa em enfermagem. Trad. de Regina Machado Garcez. Porto Alegre: Artes Médicas; 1995.

23. Saiz F. Espírito científico. [online]. Disponível em: http://geocities. <yahoo.com.brr/seuscm/espiritocientifico.html>. (5 nov. 2001).

24. Küng H. A Igreja Católica. Rio de Janeiro: Objetiva; 2002.

25. Machado VB. A manifestação do poder segundo a percepção dos enfermeiros que atuam em uma instituição hospitalar pública. [dissertação] São Paulo (SP): Escola de Enfermagem da USP; 2000.

26. Arend H. Sobre a violência. Rio de Janeiro: Relume-Dumará; 1994.

27. Arendt H. Entre o passado e o futuro. 5a ed. São Paulo: Perspectiva; 2000. 
28. Perrenoud P. Construir as competências desde a escola. Porto Alegre: Artes Médicas; 1999.

29. Domenico EBL. Referenciais de competência segundo níveis de formação superior em enfermagem: a expressão do conjunto.[tese] São Paulo (SP): Escola de Enfermagem da USP; 2003.

30. Resende E. O livro das competências: desenvolvimento das competências: a melhor auto-ajuda para pessoas, organizações e sociedade. Rio de Janeiro: Qualitymark; 2000.

31. Camponi S. Da compaixão piedosa à solidariedade. In: Conselho Federal de Medicina. Portal Médico [online]. Brasília; 2003. Disponível em: http://www.portalmedico.org.br/jornal/jornais1999/0499/Bioetica. htm (27 ago.2003).

32. Nogare PD. Humanismo e anti-humanismo: introdução à Antropologia Filosófica. 13ạ ed. Petrópolis: Vozes; 1994.

33. Abbagnano N. Dicionário de filosofia Nicola Abbagnano. Trad. de Alfredo Bosi. 4aa ed. São Paulo: Martins Fontes; 2000.

34. Dussel ED. Filosofia da Libertação na América Latina. São Paulo: Loyola; 1980.

35. Bubber M. Eu e tu: introdução e tradução de Newton Aquiles Von Zuben. 2ạ ed. São Paulo: Moraes; 1974.

36. Perdigão P. Existência e liberdade: uma introdução à filosofia de Sartre. Porto Alegre: L\&PM; 1995. 
37. Rios TA. Compreender e ensinar: por uma docência da melhor qualidade. 3ạ ed. São Paulo: Cortez; 2002.

38. Menzies I. O funcionamento das organizações como sistemas sociais de defesa contra a ansiedade. São Paulo: FGV; 1970. [Apostila].

39. Borsoi ICF. Saúde mental e trabalho: um estudo de caso da enfermagem. [dissertação] São Paulo (SP): Pontifícia Universidade Católica de São Paulo; 1992.

40. Baraúna T. Humanizar a ação para humanizar o ato de cuidar. Mundo Saúde 2003; 27(2):303-6.

41. Mezomo CJ. Hospital humanizado. Fortaleza: Premius; 2001.

42. Martin LM. A ética e a humanização hospitalar. Mundo Saúde 2003; 27(2): 206-18.

43. Selli L. Reflexões sobre o atendimento profissional humanizado. Mundo Saúde 2003; 27(2):248-53.

44. Arendt H. A dignidade da política. Rio de Janeiro: RelumeDumará, 1993.

45. Houaiss A, Villar MS, Franco FMM. Dicionário Houaiss da língua portuguesa. Rio de Janeiro: Objetiva; 2001.

46. Daron R, Parot F. Dicionário de psicologia. São Paulo: Ática; 2001.

47. Falcone EMO. A avaliação de um programa de treinamento da empatia com universitários. [tese] São Paulo (SP): Instituto de Psicologia da USP; 1998. 
48. Barrett-Lennard GT. The phases and focus of empathy. Br J Med Psychol 1993; 66(Pt 1):3-14.

49. Giles, TR. História do existencialismo e da fenomenologia. São Paulo: EPU; 1989.

50. Oliveira, SC. Reflexões filosóficas. Rio de Janeiro: 1997. 
ANEXO 1 


\section{ANEXO 2 \\ Termo de Consentimento Livre e Esclarecido}

Eu, Tânia A.Moreira Domingues, aluna regularmente matriculada no Curso de Pós-Graduação - Doutorado em Saúde do Adulto da Escola de Enfermagem da Universidade de São Paulo - USP, estou realizando um estudo qualitativo “Desvelando o sentido do Cuidado do Enfermeiro: entre a banalização e a axiologia" que tem por objetivo conhecer os valores que direcionam o agir do enfermeiro prestar cuidado. Para tanto, solicito a participação voluntária respondendo a algumas perguntas.

Esclareço que as entrevistas serão gravadas, as informações obtidas serão analisadas não sendo divulgado o nome de nenhum enfermeiro.

É garantido o direito do entrevistado de receber a transcrição de sua entrevista para posterior aprovação.

Os enfermeiros terão plena liberdade de escolha para participar ou não da pesquisa, ou poderão retirar o seu consentimento a qualquer momento, sem nenhum prejuízo, para tanto as questões norteadoras estão anexadas neste Termo.

Não há despesas pessoais para o participante em qualquer fase do estudo, como também não há compensação financeira relacionada a sua participação.

Para aqueles que concordarem em participar, a entrevista será marcada com antecedência.

Em qualquer etapa do estudo o enfermeiro poderá entrar em contato para esclarecimentos de eventuais dúvidas na Rua Napoleão de Barros, 754, tel. 5576-4430, ou qualquer dúvida sobre a ética do trabalho, entrar em contato com o Comitê de Ética em Pesquisa (CEP) Rua Botucatu, 572, 1ㅇandar, cj.14, 5571-1062.

$\mathrm{Eu}$, acredito ter sido suficientemente informado a respeito das informações que li do estudo sobre os valores que embasam o cuidado prestado pelo 
enfermeiro. Ficaram claros para mim quais são os propósitos do estudo, as garantias de confidencialidade e de esclarecimentos permanentes, que minha participação é isenta de despesas. Concordo voluntariamente em participar deste estudo e poderei retirar meu consentimento a qualquer momento, sem nenhum prejuízo.

\section{Assinatura do enfermeiro}

Data

Declaro que obtive de forma livre e voluntária o Consentimento Livre e Esclarecido deste enfermeiro para a participação neste estudo.

Tânia Arena Moreira Domingues

São Paulo, de de 2002.

Considere-se no seu cotidiano de trabalho e nas relações que você estabelece nesse cotidiano e responda:

Quais são os valores que você acredita que sustentam seu agir?

O que é para você. (os valores que forem citados)?

Como (os valores que forem citados) aparece no seu agir cotidiano de trabalho? 


\section{ANEXO 3}

\section{CARACTERI ZAÇÃO DOS SUJ EITOS}

\section{Entrevista:}

Idade:

Formação escolar

2grau: (escola)

3grau: (escola)

Onde estudou:

Qual a origem de seus pais:

avós:

Qual a profissão de seus pais:

avós:

Qual o grau de instrução de seus pais:

avós:

Qual a religião de seus pais:

avós:

Com que pessoas da sua família você convive diariamente:

Com que pessoas do âmbito social você se relaciona freqüentemente

Quais suas atividades diárias:

Em que área da enfermagem trabalha:

Freqüenta atividades em grupo qual

Freqüência

Faz leituras Tipo

Freqüência

Convívio com Artes: qual

Freqüência

Hobbies: qual

Freqüência

Religião: freqüenta

Que experiência significativa você já viveu

Que valores embasam suas opções de vida 